\title{
Free Exercise Rights of Capital Jurors
}

Brian Galle

Georgetown University Law Center, brian.galle@law.georgetown.edu

This paper can be downloaded free of charge from:

https://scholarship.law.georgetown.edu/facpub/1824

101 Colum. L. Rev. 569-604 (2001)

This open-access article is brought to you by the Georgetown Law Library. Posted with permission of the author. Follow this and additional works at: https://scholarship.law.georgetown.edu/facpub

Part of the Constitutional Law Commons, and the Criminal Law Commons 


\title{
NOTES
}

\section{FREE EXERCISE RIGHTS OF CAPITAL JURORS}

\author{
Brian Galle
}

\begin{abstract}
The Supreme Court has said that the Constitution permits trial judges to exclude from the pool of potential capital trial jurors any persons whose views on the death penalty would likely substantially impair their ability to reach an impartial verdict. This Note argues that the Court's analysis to date is incomplete, in that it omits close evaluation of potential conflicts between such exclusions and the Free Exercise Clause. The Note argues further that a court should apply strict scrutiny to any state action, such as exclusion for cause, that burdens the use of religious beliefs in the mental processes of jurors. The Note then weighs several possible government interests that might be offered to meet the test of heightened scrutiny, ultimately finding them each likely to fail. It concludes by suggesting a revised formulation of the present standard that provides more protection for the religious liberty of prospective jurors.
\end{abstract}

\section{INTRODUCTION}

Convicted murderers in the United States may not be sentenced to death either arbitrarily or automatically, by default or by pure discretion. Instead, according to a series of Supreme Court decisions beginning in the early 1970s, every defendant is entitled to an individualized determination, based upon certain morally relevant factors, whether he is to live or die. In most states, and in federal death penalty proceedings, a jury makes this determination, sometimes with review by the trial judge. Judges generally must instruct sentencing juries that they are not free to reach their decision based wholly upon their own set of values; rather, there are a predetermined collection of "aggravating" and "mitigating" factors the jury is to balance in weighing whether or not to impose a sentence of death. This structure arises primarily out of concerns that unguided jury decisionmaking tends to mirror what society at large considers irrelevant or illegitimate considerations, such as the race of the defendant or the victim.

The criminal trial process has several other mechanisms for cabining the decisions of jurors. Perhaps the most potent of these devices is the act of jury selection itself. By controlling which jurors get to decide a case, the state and the parties to a trial can also influence the jury's ultimate deliberative process. For instance, since we all generally agree that a defendant should not be convicted simply because the jurors have a personal grudge against her, we allow the judge to "exclude" jurors who are found to harbor such biases. This kind of jury control is known as exclusion "for cause." A second type of pretrial jury control is referred to 
as the "peremptory challenge," because the parties exercising it do not have to give any real reason for their choices. ${ }^{1}$

Unsurprisingly, the limits of what constitutes a permissible "cause" for exclusion are fuzzy and often fiercely debated, especially when the stakes are life and death. The Supreme Court's first modern take on challenges to prospective capital jurors came in 1968, when the Court condemned the practice of empanelling the so-called "hanging jury." Although its opinion aimed mainly at defining impermissible exclusion of jurors, the Court also implied that jurors who avowed that they would refuse to impose death in any circumstance could constitutionally be excluded for cause without violating the rights of the defendant. ${ }^{2}$ Since then, the Court has expanded on this implication, finding that any juror whose "views [on the death penalty] would "prevent or substantially impair the performance of his duties as a juror in accordance with his instructions and his oath' " can be excluded for cause. ${ }^{3}$ The same standard applies to jurors who would in most instances favor the death penalty. ${ }^{4}$

Absent from this line of cases, though, is any consideration of whether exclusion of jurors whose views on the death penalty rest on religious grounds unconstitutionally infringes upon the free exercise rights of the excluded jurors. ${ }^{5}$ This Note argues that the "substantial impair-

1. In fact, the peremptory challenge now has some limits; if it looks as if a party is using its peremptory challenges in a way that discriminates on the basis of race or gender, it can be forced to give "neutral" reasons for the strikes. See, e.g., J.E.B. v. Alabama ex rel. T.B., 511 U.S. 127, 129 (1994) (barring gender discrimination in use of peremptories by state on behalf of minor); Batson v. Kentucky, 476 U.S. 79, 100 (1986) (holding unconstitutional racially discriminatory peremptory challenges by state prosecutor).

2. See Witherspoon v. Illinois, 391 U.S. 510, 522 n.21 (1968).

3. Wainwright v. Witt, 469 U.S. 412, 424 \& n.5 (1985) (quoting Adams v. Texas, 448 U.S. 38, 45 (1980)).

4. Morgan v. Illinois, 504 U.S. 719, 729 (1992). See infra note 27.

5. Several state courts have considered whether for-cause exclusion of these jurors would violate either federal or state constitutional protections of religious liberty. The North Carolina Supreme Court rejected first a federal free exercise claim, and later a state due process religious liberty claim, explaining in both cases that exclusion was properly based on jurors' "inability to follow the law" rather than on improper discrimination. State v. Warren, 499 S.E.2d 431, 442 (N.C. 1998) (quoting State v. Davis, 386 S.E.2d 418, 427 (N.C. 1989)). The same logic has been used to reject challenges to exclusions of religious objectors under the Tennessee Constitution. See State v. Jones, 789 S.W.2d 545, 547 (Tenn. 1990); State v. Bobo, 727 S.W.2d 945, 949 (Tenn. 1987); Wolf v. Sundquist, 955 S.W.2d 626, 631 (Tenn. Ct. App. 1997).

New Mexico has reached a similar result in interpreting its constitutional proviso that "[t]he right of any citizen of the state to . . sit upon juries, shall never be restricted, abridged or impaired on account of religion." N.M. Const. art. VI, § 3; see State v. Clark, 990 P.2d 793, 802-03 (N.M. 1999) (finding no violation where exclusion based on opposition to death penalty represents juror's inability to perform duty rather than exclusion based upon religious opinion or affiliation).

The United States Supreme Court has found that use of peremptory-as opposed to for-cause-challenges, by either the state or by private parties, systematically to exclude potential jurors on the basis of their race or sex impermissibly violates the rights of citizens to serve on a jury. See J.E.B., 511 U.S. at 129; Batson, 476 U.S. at 100 . Some commentators 
ment" standard, in failing to recognize that there are important differences for First Amendment purposes ${ }^{6}$ between jurors who would always vote for or against the death penalty and those who are only likely or inclined to do so, permits states unconstitutionally to exclude some jurors. ${ }^{7}$ Part 1 explains how the narrowing of what was once an expansive

have argued that use of peremptory challenges based on religious affiliation should also be prohibited by Batson principles. See Cheryl G. Bader, Batson Meets the First Amendment: Prohibiting Peremptory Challenges That Violate a Prospective Juror's Speech and Association Rights, 24 Hofstra L. Rev. 567, 593-601 (1996); Morris B. Hoffman, Peremptory Challenges Should Be Abolished: A Trial Judge's Perspective, 64 U. Chi. L. Rev. 809, 839 (1997); Angela J. Mason, Note, Discrimination Based on Religious Affiliation: Another Nail in the Peremptory Challenge's Coffin?, 29 Ga. L. Rev. 493, 521-25 (1995). But see J. Suzanne Bell Chambers, Applying the Break: Religion and the Peremptory Challenge, 70 Ind. L.J. 569, 570 (1995) (arguing against extension of Batson). So far, only a few courts have taken up the invitation. See United States v. Greer, 939 F.2d 1076, 1086 (5th Cir. 199I) (holding that Batson limits "race, religion, and national-origin-based peremptory challenges"); State v. Gilmore, 511 A.2d 1150, 1157 (N.J. 1986) (claiming that Batson would apply to strikes based on either race or religion). But see, e.g., State v. Davis, 504 N.W.2d 767, 768-71 (Minn. 1993) (ruling that Batson doctrine does not apply to religion). A pair of commentators have mentioned for-cause exclusion obliquely, suggesting that it would be permissible where peremptory challenges of jurors based on religion would not. See Benjamin Hoorn Barton, Note, Religion-Based Peremptory Challenges After Batson v. Kentucky and J.E.B. v. Alabama: An Equal Protection and First Amendment Analysis, 94 Mich. L. Rev. 191, 211-12 (1995); Gary C. Furst, Note, Will the Religious Freedom Restoration Act Be Strike Three Against Peremptory Challenges?, 30 Val. U. L. Rev. 701, 743-44 (1996).

6. While the First Amendment argument developed in this Note relies in some part on fundamental notions, such as freedom of thought, that might be said to underlie both the religion and speech clauses, see infra text accompanying notes 52-58, it focuses doctrinally only on the potential free exercise claim. As a result, this Note does not address the possibility that a strongly politically motivated or merely racist juror might make similar arguments to gain admission to a jury from which she would otherwise be barred. An indepth exploration of the distinguishing features between the three situations from a moral viewpoint-for instance, whether as a matter of political philosophy faith-based reasoning is especially desirable or undesirable in capital sentencing-is an important discussion, but one well beyond the scope of this Note. For a general discussion of the intersections between legal and religious modes of thought, see Kent Greenawalt, Private Consciences and Public Reasons 159-63 (1995) (considering whether legislators and citizens ought to rely on religious or other "comprehensive" views in making political judgments).

Pragmatically speaking, though, a free exercise claim might succeed here where a viewpoint discrimination-type claim has already failed. See Lockhart v. McCree, 476 U.S. $162,175-76$ (1986) (rejecting claim that jurors opposed to death penalty represent a distinctive group subject to discrimination by for-cause exclusion). As this Note's focus on the doctrine demonstrates, free exercise claims present a distinctive set of interests to be balanced-interests simply not considered in the Witherspoon-Wainuright line of cases. Free exercise also has never been narrowed by a "limited public forum" exception in the way political speech has.

7. Although in theory a juror could bring a suit for enforcement of these claimsunder 42 U.S.C. $\$ 1983$ (2000), for example-the more common situation will be one in which one of the parties will raise a challenge to exclusion on the juror's behalf. The Supreme Court has approved this practice, despite the possible standing issues it raises, because jurors will rarely have a sufficient incentive to undertake the costs of litigation on their own behalf. See Georgia v. McCollum, 505 U.S. 42, 55-56 (1992). 
role for juror discretion led to the development of the substantial impairment rule. Part 1 II begins the First Amendment analysis of the substantial impairment standard by considering what level of scrutiny would be applied under prevailing free exercise doctrine. This Part argues that exclusion of jurors based on their statement of religiously motivated opinions is not controlled by the leading case, Employment Division v. Smith. ${ }^{8}$ Relying on both explicit and implicit exceptions to Smith, this Part concludes that a showing of compelling government interest is needed to sustain the rule. Part III examines several possible government interests and weighs them against the demands of strict scrutiny. This Note concludes that these potential interests, while perhaps justifying exclusion of jurors who are absolutely for or against the death penalty, are insufficient to survive heightened scrutiny in the case of jurors who are only "substantially impaired."

\section{The Evolution of the Wainwright Standard}

Until 1972, many states left the decision whether or not to impose a death sentence to what was, in effect, the unguided discretion of the jurors. ${ }^{10}$ In that year, though, the Supreme Court declared that the death penalty was unconstitutional as administered by the State of Georgia. ${ }^{11}$ Although Georgia's statute was putatively aimed at allowing sentencing based on moral factors, in fact the jurors were permitted the "uncontrolled discretion" to impose a sentence for whatever reason moved them. ${ }^{12}$ While the Court was deeply divided as to its rationale, five Justices did agree that at a minimum such wide discretion was too likely to result in arbitrary and possibly racist application of the death penalty: "Under these laws no standards govern the selection of the penalty. People live or die, dependent on the whim of one man or of 12." 13 Thus, the law violated the Eighth Amendment's prohibition against cruel and unusual punishment: "It would seem to be incontestable that the death penalty inflicted on one defendant is 'unusual' if it discriminates against him by reason of his race, religion, wealth, social position, or class, or if it is imposed under a procedure that gives room for the play of such prejudices." 14

In response to Furman, Georgia and the other states revised their capital punishment statutes to impose limits and guidance on jury deci-

8. 494 U.S. 872 (1990).

9. Wainwright v. Witt, 469 U.S. at 412, 424 (1985). In general, this conclusion applies to jurors who are inclined either for or against a death verdict. However, because of the structure of most death penalty statutes, the argument for jurors who favor death is weaker. See infra Part III.B.1.

10. See Furman v. Georgia, 408 U.S. 238, 252-53 (1972) (Douglas, J., concurring).

11. Id. at $239-40$ (per curiam).

12. Id. at 253 (Douglas, J., concurring).

13. Id.

14. Id. at 242. 
sions. Many of these reforms followed the example of the Model Penal Code in establishing a set of permitted "aggravating" and "mitigating" factors that a judge or jury is required to weigh. The decisionmaker is sometimes also required to make explicit which factors were relied upon in reaching the ultimate decision. ${ }^{15}$ Four years after Furman, the Court approved a revised Georgia statute that set out an exclusive list of ten aggravating factors that could support a verdict of death, but allowed consideration of mitigating and individually insufficient aggravating factors as "otherwise authorized by law." 16 ln upholding Georgia's sentencing scheme, the Court repeatedly emphasized the importance of detailed, binding instructions to the jury. ${ }^{17}$

For all of the Court's emphasis on guidance and careful instruction, it is significant that the Georgia statute leaves substantial opportunities for jurors to employ their individualized judgment. ${ }^{18}$ 1ndeed, the Court has subsequently held that the use of individualized moral assessments of death penalty defendants is not only permissible but mandatory. ${ }^{19}$ Fundamental respect for individual human dignity, embodied in the Eighth Amendment, "requires consideration of the character and record of the individual offender and the circumstances of the particular offense as a constitutionally indispensable part of the process of inflicting the penalty of death."20

Thus, a death penalty juror seems bound by a pair of arguably contradictory obligations. On the one hand, she must follow her conscience, in assuring that each defendant receives particularized moral consideration of his unique human circumstances. On the other hand, she must also follow "fixed rules of law." 21 Of course, the two demands do not necessarily conflict, especially if there is widespread agreement in society about the moral system undergirding the rules of law. ${ }^{22}$

15. See Gregg v. Georgia, 428 U.S. 153, 193 (1976).

16. Id. at 164-66. The present Georgia statute is identical in all significant respects. See Ga. Code Ann. § 17-10-30 to -31.1. (1997).

17. Gregg, 428 U.S. at 193, 195.

18. See id. at 164 ("The scope of the nonstatutory aggravating or mitigating circumstances is not delineated in the statute.").

19. See McKoy v. North Carolina, 494 U.S. 433, 442 (1990) ("The Constitution requires States to allow consideration of mitigating evidence in capital cases."); Eddings $v$. Oklahoma, 455 U.S. 104, 110-16 (1982) (reversing death sentence where trial judge had refused to consider defendant's family history as a mitigating factor); Lockett v. Ohio, 438 U.S. 586, 604 (1978) (plurality opinion) (concluding that "the Eighth and Fourteenth Amendments require that the sentencer, in all but the rarest kind of capital case, not be precluded from considering, as a mitigating factor, any aspect of a defendant's character or record and any of the circumstances of the offense that the defendant proffers") (citation omitted); Woodson v. North Carolina, 428 U.S. 280, 303-05 (1976) (opinion of Stewart, Powell, and Stevens, JJ.).

20. Woodson, 428 U.S. at 304 (opinion of Stewart, Powell, and Stevens, JJ.).

21. Gregg, 428 U.S. at 193.

22. There is a lively scholarly debate about the compatibility of rule-based criminal systems with the expression of community moral sense. See, e.g., Alan C. Michaels, 
These changes brought a corresponding shift in the law of capital jury selection. Under the pre-Furman regime, the Court had held that the state had an interest in excluding for cause at voir dire only those jurors who would "automatically" reject the death penalty, regardless of the facts of the case. ${ }^{23}$ In 1985, the Court expanded the class of excludable jurors to include those whose views would "prevent or substantially impair the performance of [their] duties as a juror in accordance with [their] instructions and [their] oath." 24 Jurors, Justice Rehnquist explained, must "apply the law." 25 Before Furman, the law required only that jurors at least contemplate imposition of the death penalty. Now, however, they are required also to follow a statutorily prescribed procedure in making their decisions. Thus, the Court concluded, a juror whose views would likely "substantially impair" his performance as a juror-i.e., a juror who would not follow the procedure-was also likely not "apply[ing] the law." 26 The same standard applies whether the juror is

"Rationales" of Criminal Law Then and Now: For a Judgmental Descriptivism, 100 Colum. L. Rev. 54, 66-71 (2000) (summarizing the opposing views).

23. Witherspoon v. Illinois, 391 U.S. 510, 522 n.21 (1968); accord Davis v. Georgia, 429 U.S. 122, 123 (1976). Voir dire is the process by which a judge or, on occasion, the attorneys for parties examine prospective jurors.

24. Wainwright v. Witt, 469 U.S. 412, 424 (1985). Justice Rehnquist suggests that the "substantially impair[ed]" standard had already been set out in an earlier case, Adams v. Texas, 448 U.S. 38 (1980). He acknowledges, though, that before Witt there was considerable confusion among lower courts as to whether the Witherspoon or the Adams test was in force, or whether there was any meaningful difference between the two in view of the fact that Adams had found exclusion improper. Wainwright, 469 U.S. at 421.

25. Id.

26. Id. at 424, 426; see also John H. Garvey \& Amy V. Coney, Catholic Judges in Capital Cases, 81 Marq. L. Rev. 303, 338 (1998) ("The problem with [a juror who would automatically vote to impose the death penalty] is not that he reaches a forbidden conclusion. It is that he refuses to go through the process required to get there.").

There is some ambiguity in Justice Rehnquist's opinion about how certain a judge must be that a juror will be "substantially impair[ed]." While he is clear that impairment need not be found with "unmistakable clarity," a few lines later he seems to endorse exclusion where a judge is merely "left with the definite impression" that a juror will not apply the law. Id. at 424-26. Attempts by other courts to further refine the level of certainty have been inconclusive. Compare, e.g., Riley v. State, 889 S.W.2d 290, 301 (Tex. Crim. App. 1993) (en banc) (ruling that a juror who presents a "substantial likelihood that he will balk at the task or falsify an answer" can be excluded for cause), with Farris v. Johnson, 967 F. Supp. 200, 207-08 (N.D. Tex. 1997) (arguing that Riley represents an incorrect interpretation of federal law). While a few courts have attempted to fashion bright-line rules for certain types of jurors, there remains wide variation among state and federal courts in the minimum level of "impairment" that can justify exclusion. For instance, jurors who seem only to lean towards a given verdict are sometimes excludable and sometimes not. Compare United States v. Barnette, 211 F.3d 803, 812 (4th Cir. 2000) (excluding juror who stated "[i]f given the two choices, I would weigh heavily on not wanting to go the death penalty") (alteration in original), with United States v. Hall, 152 F.3d 381, 409-10 (5th Cir. 1998) (holding that venireperson who leaned toward death did not have to be excluded), Jarrell v. State, 413 S.E.2d 710, 712 (Ga. 1992) (same), and State v. Lucky, 755 So. 2d 845, 849-51 (La. 1999) (finding that venire member who would require "pretty heavy evidence" of mitigation to render life sentence was properly seated 
predisposed to vote for or against death. ${ }^{27}$ The question for this Note will be whether the incremental protection of "the law" achieved by this rule is a sufficiently compelling state interest to justify restrictions of a First Amendment free exercise right.

\section{The INTERESTS OF THE JUROR}

This Part considers what level of scrutiny should be applied to-and, correspondingly, the strength of the state interest needed to justify-forcause exclusion of religiously motivated capital jurors. After considering briefly the possibility that such exclusion constitutes religious discrimination, this Part turns to examining the leading precedents on laws of general applicability that have the incidental effect of burdening religious exercise. It concludes by finding that heightened scrutiny is likely for incidental-burden laws that target belief rather than actions.

on jury). Courts have also disagreed as to whether jurors who simply say they are unsure they could follow the law are properly excused. Compare Gall v. Parker, 231 F.3d 265, 331-32 (6th Cir. 2000) (holding trial court's exclusion of juror "uncertain[ ] as to how the option of a death sentence would affect his decision" was error), with Castro v. Ward, 138 F.3d 810, 824-25 (10th Cir. 1998) (upholding exclusion of juror who "[did] not know ... whether she [could] give the death penalty"), Alley v. Bell, 101 F. Supp. 2d 588, 652-53 (W.D. Tenn. 2000) (excluding juror who stated he was unsure he could follow law), and State v. Gentry, 888 P.2d 1105, 1143-44 (Wash. 1995) (en banc) (upholding exclusion of uncertain juror). Lastly, there are sharp divisions over whether a juror whose answers appear to indicate a firm view towards capital punishment, but who nonetheless avers he or she would still follow the judge's instructions, must be excluded. Compare State v. Anderson, 4 P.3d 369, 374-75 (Ariz. 2000) (en banc) (ruling that juror who wrote both that she could not impose death and that she would follow law was not necessarily excludable without further questioning), and Clark v. State, 929 S.W.2d 5, 8-9 (Tex. Crim. App. 1996) (en banc) (holding jurors who state unequivocally that they will obey the judge's instructions must be admitted), with State v. Griffin, 741 A.2d 913, 936 (Conn. 1999) (sustaining exclusion of juror who stated that while she would not vote for a death penalty she "would follow the law").

The end result of this doctrinal uncertainty is that, as a practical matter, the trial judge's decision is essentially discretionary. The judge's assessment of the juror is deemed a factual determination, with attendant deference from any reviewing court. See Wainwright, 469 U.S. at 429; Gall, 231 F.3d at 331; Hale v. Gibson, 227 F.3d 1298, 1318 (10th Cir. 2000); Barnette, 211 F.3d at 812-13; Spivey v. Head, 207 F.3d 1263, 1275 (11th Cir. 2000); State v. Longworth, 438 S.E.2d 219, 222 (S.C. 1993); Colburn v. State, 966 S.W.2d 511, 517 (Tex. Crim. App. 1998) (en banc); Gentry, 888 P.2d at 1143. Judges who are so inclined have great power to control the makeup of the jury with little fear of close appellate review of their determinations.

27. See Morgan v. 1llinois, 504 U.S. 719, 729 (1992). There might be an overly literal reading of Morgan in which only jurors who would "automatically vote for the death penalty in every case" are excludable. 1d. That reading overlooks the fact that Morgan makes no effort to distinguish pro-death jurors from jurors opposed to capital punishment, for whom the Court previously had developed a sophisticated rationale justifying exclusion even when the juror gave only the "definite impression" she would be unlikely to vote for death. Wainuright, 469 U.S. at 424-26; see supra notes 23-26 and accompanying text. Indeed, far from rejecting Wainwright, Morgan explicitly adopts its reasoning. Morgan, 504 U.S. at $734-35$. 


\section{A. Prevailing Supreme Court Free Exercise Doctrine}

Modern claims of free exercise violations are largely governed by $\mathrm{Em}$ ployment Division v. Smith, a 1990 Supreme Court decision sharply limiting the shelter provided by the Free Exercise Clause against laws of general applicability. ${ }^{28}$ Alfred Smith and Galen Black were fired from their jobs at a drug rehabilitation center because, as part of their participation in a Native American Church ritual, they consumed peyote, an illegal hallucinogen. The State of Oregon subsequently denied Smith and Black unemployment benefits, finding that they had been terminated for "misconduct," and Smith and Black sued. By the time their case reached the Supreme Court for a second time, in 1989, the main question was whether or not Oregon's refusal to exempt religious users of peyote from its drug laws violated the Free Exercise Clause. ${ }^{29}$

The Court rejected Smith and Black's challenge, announcing what was, arguably, a broad reinterpretation of free exercise jurisprudence. ${ }^{30}$ In an opinion by Justice Scalia that seemed to follow closely the centuryold case of Reynolds $v$. United States, ${ }^{31}$ the Court held that where a burden is "merely the incidental effect of a generally applicable and otherwise valid provision, the First Amendment has not been offended." 32 Thus, any law that affected conduct engaged in for both religious and nonreligious purposes would not receive the heightened scrutiny that at least some laws burdening religious activity had often been subject to in the past. ${ }^{33}$ In fact, since the majority opinion moves directly from its rejection of the compelling interest test to an affirmation of Oregon's decision to deny benefits, ${ }^{34}$ it appears that Smith does not permit even rational

28. 494 U.S. 872 (1990). For the most part, this Note accepts Smith uncritically. Readers interested in more intensive evaluation of the decision are recommended to Douglas Laycock, The Remnants of Free Exercise, 1990 Sup. Ct. Rev. 1 (critiquing the theoretical conceptions upon which Smith relies and surveying the broader impact of the decision); William P. Marshall, In Defense of Smith and Free Exercise Revisionism, $58 \mathrm{U}$. Chi. L. Rev. 308 (1991) (acknowledging some jurisprudential failings but defending policy results of Smith); Michael W. McConnell, Free Exercise Revisionism and the Smith Decision, 57 U. Chi. L. Rev. 1109 (1990) (criticizing Smith as methodologically problematic and philosophically inconsistent with underlying premises of First Amendment).

29. Smith, 494 U.S. at 874-76.

30. See Smith, 494 U.S. at 907-08 (Blackmun, J., dissenting); McConnell, supra note 28 , at $1120-28$.

31. 98 U.S. 145 (1878). In Reynolds, the Supreme Court upheld against a free exercise challenge a federal law prohibiting bigamy and polygamy in the Utah territory. After examining the history of the First Amendment, the Court concluded that while "Congress was deprived of all legislative power over mere opinion," it remained free to control "actions which [arel in violation of social duties or subversive of good order." Id. at 164. Where regulating marriage was within the power of Congress, the Court decided, no individual could claim exemption from generally applicable marriage laws.

32. Smith, 494 U.S. at 878 .

33. See id. at $907 \&$ n.l (Blackmun, J., dissenting).

34. See id. at 888-90. 
basis review of neutral, generally applicable state activity challenged on free exercise grounds. ${ }^{35}$

1t is, however, still possible to make viable free exercise claims. Smith itself includes exceptions to its general prohibition against balancing. ${ }^{36}$ The next section considers the viability of these loopholes.

\section{B. Does Smith Apply to For-Cause Exclusion of Jurors?}

1. Religious Discrimination. - Although Smith limits the force of free exercise claims against neutral laws of general applicability, it acknowledges that state action "specifically directed at ... religious practice[s]" would likely violate the Constitution. ${ }^{37}$ This exception embraces both statutes that target religion on their face ${ }^{38}$-for example, by barring ministers from holding public office ${ }^{39}$ - as well as those that are so underinclusive it can fairly be said that they operate upon "acts or abstentions only when they are engaged in for religious reasons, or only because of the religious belief that they display." 40

While challenged jurors might suggest that for-cause exclusion is facially discriminatory, they are unlikely to succeed. The initial claim would probably look something like Batson: "You found out 1 have deeply held religious beliefs, and then you moved to remove me for cause." There is, though, a major difference between the Batson prohibition and the for-cause exclusion of, for example, Catholics who state that they

35. Cf. id. at $889 \mathrm{n.5}$ (" $[\mathrm{I}] \mathrm{t}$ is horrible to contemplate that federal judges will regularly balance against the importance of general laws the significance of religious practice."). For a scholarly argument to the same effect, see Jonathan C. Lipson, On Balance: Religious Liberty and Third-Party Harms, 84 Minn. L. Rev. 589, 643 (2000).

36. In addition, Congress made a short-lived effort to overturn Smith through a piece of legislation, the Religious Freedom Restoration Act (RFRA), 42 U.S.C. $\$ 2000$ bb (1994). Although the Court struck down RFRA as it applied to the states, see City of Boerne v. Flores, 521 U.S. 507, 536 (1997), there might be an argument that RFRA still binds the federal government. Cf. In re Yotung, 141 F.3d 854, 861 (8th Cir. 1998) (finding that RFRA demonstrates Congress's intent to "modify the United States bankruptcy laws" to provide heightened statutory protection for religious liberty); Carol M. Kaplan, Note, The Devil is in the Details: Neutral, Generally Applicable Laws and Exceptions from Smith, 75 N.Y.U. L. Rev. 1045, 1063-64 (2000) (noting doctrinal uncertainty).

37. Smith, 494 U.S. at 878 ; see also id. at 886 n.3 ("[W]e strictly scrutinize governmental classifications based on religion.").

38. See id. at 877 (citing Larson v. Valente, 456 U.S. 228, 245 (1982); McDaniel v. Paty, 435 U.S. 618 (1978); Torcaso v. Watkins, 367 U.S. 488 (1961); Fowler v. Rhode lsland, 345 U.S. 67, 69 (1953); United States v. Ballard, 322 U.S. 78, 86-88 (1944)).

39. See McDaniel, 435 U.S. at 619.

40. Smith, 494 U.S. at 877 (emphasis added); accord Church of the Lukumi Babalu Aye, Inc. v. City of Hialeah, 508 U.S. 520, 537-40 (1993). Lukumi dealt with the claim by members of the Santeria faith, whose practices include animal sacrifice, that a city ordinance limiting animal slaughter was so underinclusive as to constitute discrimination. The city's rules contained exceptions not only for commercial slaughter but also for other religious killings-kosher slaughter, for instance. In effect, it was only illegal to kill animals when the killing was part of a Santeria ritual. 
could not impose the death penalty in any circumstance. ${ }^{41}$ Where the peremptory challenge cases forbid exclusion of jurors solely because of their race, the Catholic juror is arguably excluded not because of his religion, but because of his views. Not everyone who considers himself a Catholic adheres to every position put forward by the Pope, and, as the Court has recognized, even the religious zealot may "nonetheless subordinate his personal views to what he perceive[s] to be his duty to abide by his oath as a juror and to obey the law of the State."42 Under Wainwright and the related cases, jurors are excludable where their views, whatever the origin of the views, substantially impair their ability to follow the court's instructions. ${ }^{43}$ Thus, a juror excluded not merely because of her religious affiliation, but because she indicates that she would not be willing to subordinate her personal views, arguably has not been classified according to her religion. ${ }^{44}$

Nor is it likely that a court would accept the claim that for-cause exclusion is so underinclusive as to be "directed at" religion. The practice of excluding biased jurors is underinclusive to some extent, in that it is probably impossible to detect and exclude all jurors who have an undesirable bias. ${ }^{45}$ A very broad view of "religion" might also make the pool of

41. In addition to the Catholic Church, Quakers, Unitarians and Universalists, and certain other Protestant and Jewish denominations, have all denounced the death penalty at various times. See The Churches Speak On: Capital Punishment (J. Gordon Melton ed., 1989); Garvey \& Coney, supra note 26, at 303-04.

42. Witherspoon v. Illinois, 391 U.S. 510,514 n.7 (1968). For a thoughtful argument that Catholic judges, at least, should refuse to take part in most aspects of capital trials, see Garvey \& Coney, supra note 26 , at 306-31.

43. See Wainwright v. Witt, 469 U.S. 412, 424 (1985). 1t may be, though, that the decision not to defer to the state is itself premised on a religious belief-for instance, if the juror's religion asserts that individuals have an obligation to elevate their spiritual obligations above their secular duties. It might be possible to respond to this argument by saying that it misses the point: Exclusion is not because of the religious choice qua religious choice, but simply because the juror's answers are within the category of "biased" responses.

44. See City of Boerne v. Flores, 521 U.S. 507, 535 (1997) ("When the exercise of religion has been burdened in an incidental way by a law of general application, it does not follow that the persons affected have been burdened any more than other citizens, let alone burdened because of their religious beliefs.") (emphasis added); Gillette v. United States, 401 U.S. 437, 462 (1971) (holding that conscription statute that fails to allow conscientious objector status for those with religious scruples only as to select wars does not target any particular theological position, even though some religions teach that followers must not engage in unjust wars); State v. Willoughby, 892 P.2d 1319, 1335 (Ariz. 1995) (in banc); State v. Warren, 499 S.E.2d 431, 442 (N.C. 1998); Kent Greenawalt, All or Nothing at All: The Defeat of Selective Conscientious Objection, 1971 Sup. Ct. Rev. 31, 73-75, 82-90.

45. The argument, elaborated in infra Part I11,A, that "bias" will rarely be relevant to death penalty jurors, might also undermine the identification of for-cause exclusion as "neutral." If the secular policy advanced to justify a law of general applicability is nonsensical, a court might be inclined to find it a pretext for religious discrimination. See Gillette, 401 U.S. at 453-54. Although preventing bias is not a sufficiently weighty state interest to overcome strict scrutiny, see infra Part III.A, it probably is strong enough to say 
jurors who are excluded for nonreligious bias relatively small. Even this showing, though, is not enough to survive Smith, which demands that religious activity be targeted "only when . . . engaged in for religious reasons." 46 Under this prong of Smith, then, a court would not find exclusion for cause as deserving of heightened scrutiny.

2. Belief and Conduct. - By its terms, Smith purports to apply only to laws that regulate acts. ${ }^{47}$ Indeed, any comments that the Court made on any other score would be dicta, since, as it acknowledges, there was "no contention that Oregon's drug law represents an attempt to regulate religious beliefs [or] the communication of religious beliefs." 48 Instead, the majority relies upon the rule set out in Reynolds, where Chief Justice Waite acknowledged frankly that "the legislative powers of the government reach actions only, and not opinions." 49 Of course, jurors are not excludable simply for believing that the death penalty is inappropriate; they are excused for saying during voir dire that they would not set aside this belief. Is their speech an "action"?

We might resolve this question without resorting to the ample free speech precedent on the topic. ${ }^{50}$ If beliefs are to be protected from discrimination, and if, in general, beliefs are unknowable (and, hence, incapable of being subjected to discrimination) unless expressed through some means, then there must be at least some minimum form of communicating beliefs that is treated as if it were part and parcel of the belief itself, even if in fact we know that it is distinct. This principle does not

that it "exists," which is all that is required under Gillette to meet the test of neutrality. Gillette, 401 U.S. at 454.

46. Employment Div. v. Smith, 494 U.S. 872, 877 (1990) (emphasis added); Gillette, 401 U.S. at 453-54; Follett v. Town of McCormick, 321 U.S. 573, 580-82 (1944) (Roberts, J., dissenting) (asserting that the First Amendment does not protect religion from "nonoppressive" and "nondiscriminatory" taxation). But see In re Summers, 325 U.S. 561, 576-78 (1945) (Black, J., dissenting) (arguing that Illinois state bar rule requiring oath to support state constitution targeted religion, where applicant's refusal to take oath was based on his religious objection to conscription, and he was otherwise qualified for membership); Kenneth D. Sansom, Note, Sharing the Burden: Exploring the Space Between Uniform and Specific Applicability in Current Free Exercise Jurisprudence, 77 Tex. L. Rev. 753, 769-70 (1999) (arguing that Lukumi implies that secular departures from a general statutory scheme must be "matched" by exemptions for religious exercise). Although the Sansom Note makes a good argument, it probably is inconsistent with the plain language of Smith and Gillette.

47. See Smith, 494 U.S. at 878-79 ("We have never held that an individual's religious beliefs excuse him from compliance with an otherwise valid law prohibiting conduct .... 'Laws,' we said, 'are made for the government of actions, and while they cannot interfere with mere religious belief and opinions, they may with practices.'" (quoting Reynolds v. United States, 98 U.S. 145, I66 (I878))); see also Boerne, 52I U.S. at 539 (Scalia, J., concurring) (claiming Smith stands for the proposition that religious exercise "shall be permitted so long as it does not violate general laws governing conduct").

48. Smith, 494 U.S. at 882.

49. Reynolds, 98 U.S. at 164 (quoting Letter from Thomas Jefferson to Nehemiah Dodge and Others, a Committee of Danbury Baptist Association (Jan. 1, 1802)).

50. For a concise summary of that precedent, see Laurence H. Tribe, American Constitutional Law 825-32 (2d ed. 1988). 
require protection of every mode of expression; if we want to minimize the damage to our sense of the real distinction between act and belief, we could extend protection only to the least "active" means available to make belief evident in a given circumstance. ${ }^{51}$ In any event, we probably would not need to belabor the point in distinguishing Smith, since again by its terms the opinion excepts communication of religious beliefs.

The problem with this argument is that the speech of the juror that is penalized is, in fact, a prediction of action. The juror is describing how he will likely vote at the end of the trial. Since the court will probably have no remedy for a biased juror who votes against a death sentence for reasons other than those laid out in the court's instructions, the only possible way to reach the "action" of the vote is to exclude based on a juror's speech during voir dire. The success of this counterargument, though, depends on the assumption that preventing the misguided vote of a juror is itself regulating action and not belief or speech. It could be argued that the juror is, in fact, penalized for saying she will do what other jurors do covertly. Alternately, we could observe that the physical fact of one juror's vote against death is the same as any other's. His hand in the air, her note on the verdict pad, is the same. In fact, the state is not attempting to regulate the ballot itself at all; the state's interest is unaffected by whether a prospective juror ultimately votes for or against death. Instead, the judge is seeking to control the mental processes of the jurors-ensuring that they follow the prescribed mechanism for deliberating and deciding which sentence to impose.

This leaves us with the critical question: If a law regulates mental activity, is it directed at "belief" or at "action"? There are plausible linguistic arguments in either direction, and Smith does not directly address the issue. ${ }^{52}$ A long tradition of Supreme Court pronouncements and scholarly commentary holds that the First Amendment announces a right of freedom of thought and conscience. ${ }^{53}$ Much of the force of this argu-

51. This is not to claim that such an approach would square with First Amendment precedent. The point is only that giving religious speech protection coextensive with religious belief need not obliterate tbe distinction between action and idea.

52. It appears that no court or commentator has yet considered the possibility that Smith even contains an implicit "belief" exception, let alone the limits of such an exception.

53. See, e.g., Wooley v. Maynard, 430 U.S. 705, 714 (1977) (describing free speech as part of "broader concept of 'individual freedom of mind" (quoting W. Va. State Bd. of Educ. v. Barnette, 319 U.S. 624, 637 (1943))); Girouard v. United States, 328 U.S. 61, 68 (1946) (declaring that Bill of Rights represents a "victory for freedom of thought"); Barnette, 319 U.S. at 642 ("[N]o official . . can prescribe what shall be orthodox in politics, nationalism, religion, or other matters of opinion . . . .); id. at 655 (Frankfurter, J., dissenting) ("Law is concerned with external behavior and not with the internal life of man."); Steven J. Heyman, Righting the Balance: An Inquiry into the Foundations and Limits of Freedom of Expression, 78 B.U. L. Rev. 1275, 1326-27 (1998) (claiming that freedom of speech includes freedom of thought a fortiori, and that Barmette and its progeny stand for principle that " $[t]$ he inner self is inviolable; any intrusion into it, or attempt to expose it to others against its will, does violence to this inner freedom"); Samuel 
ment seems to derive from the libertarian premise that the state's legitimate role begins only "whenever activities begin to affect or collide with liberties of others or of the public."54 Thus the Court has often described the opinion/action dichotomy as one demarcated by the line where action is "in violation of social duties or subversive of good order." 55 Yet this formulation is problematic, since the determination whether even physical activity violates social duties can be controversial. ${ }^{56}$ Another difficulty is that thought, too, can undermine the social order-when it leads to undesirable outcomes that the law is powerless to prevent before set in action. Unguided jurors are a perfect example of this phenomenon: If they harbor racist thoughts, they can undermine our goal of equal protection under the law, and our only opportunity to prevent racist outcomes is to censor the thought—strike the juror from the jury.

Strict scrutiny presents an attractive solution to this dilemma. ${ }^{57}$ Mental activity, it has been argued, is harmful only when it is predictive of or conducive to adverse nonmental outcomes. If we stand with Justice Jackson in placing a premium on free thought, we ought only to limit the exercise of religious conscience where the adverse outcomes it portends

D. Warren \& Louis D. Brandeis, The Right to Privacy, 4 Harv. L. Rev. 193, 193, 195-96 (1890) (arguing that law protects "man's spiritual nature ... his feelings and his intellect"). Laws that seek to regulate thought directly are exceedingly rare, if not nonexistent. Barnette, for example, was a challenge by a young Jehovah's Witness to compulsory flag salute. Writing for the majority, Justice Jackson noted that it was unclear whether the state sought genuinely to require mental obeisance to the flag or only that students "simulate" it. Barnette, 319 U.S. at 633.

These cases illustrate nicely why the Free Speech Clause is not a non sequitur when it follows on the heels of the religion clauses in the Bill of Rights. There is a certain core of underlying principles common to most or all of the First Amendment, and cases which speak to that core can have true doctrinal value no matter whether they begin their analysis in "speech" or "free exercise." Justice Jackson, for example, never even bothers to decide under which particular clause Barnette's claim should fall. See id. at 639-42 (analyzing "the First Amendment to our Constitution").

54. Prince v. Massachusetts, 321 U.S. 158, 177-78 (1944). This was also a Justice Jackson opinion.

55. Reynolds v. United States, 98 U.S. 145, 164 (1878); see also Employment Div. v. Sinith, 494 U.S. 872, 885 (1990) (analyzing “government's ability to enforce generally applicable prohibitions of socially harmful conduct").

56. Compare Reynolds, 98 U.S. at 164-66 (finding evils of polygamy justify government regulation), with Griswold v. Connecticut, 381 U.S. 479, 485-86 (1965) (holding law outlawing contraceptives intrudes on constitutional right to privacy in marital relationship). For an argument on the Griswold side, see Lipson, supra note 35, at $591 \mathrm{n.7}$ (arguing that polygamy and peyote use do not involve public harms); id. at 594 ("[W1here third parties are likely to be harmed by an exemption, courts should not recognize a presumption in favor of religious claimants.").

57. "Strict scrutiny," of course, describes the practice by federal courts of requiring both a compelling state interest and a very close nexus between that end and the means chosen to accomplish it before sustaining the enactment. See, e.g., Consol. Edison Co. v. Pub. Serv. Comm'n, 447 U.S. 530, 540 (1980) (applying strict scrutiny); First Nat'l Bank of Boston v. Bellotti, 435 U.S. 765, 786 (1978) (same); Buckley v. Valeo, 424 U.S. 1, 25 (1976) (per curiam) (same). 
cannot be prevented by regulation on physical activities. ${ }^{58}$ This is precisely what the "least restrictive means" branch of strict scrutiny accomplishes. ${ }^{59}$ Thus, the general philosophical thrust of Supreme Court precedent suggests that regulation of mental activity should be exempted from Smith's bar on balancing for laws prohibiting "conduct" or "actions," and that strict scrutiny should be applied instead. ${ }^{60}$

3. The Sherbert Exception. - Smith also grudgingly permits an exception for cases substantially resembling the facts in Sherbert $v$. Verner. ${ }^{61}$ Summarizing the Sherbert line, Justice Scalia concludes that "where the State has in place a system of individual exemptions, it may not refuse to extend that system to cases of 'religious hardship' without compelling reason." 62 In other words, some kinds of governmental decisionmaking are not laws of "general applicability," in which society's interests as a whole loom over incidental burdens on individuals; rather, some types of decisions are designed to consider only the welfare of directly-impacted individuals. ${ }^{63}$ Arguably, Smith preserves Sherbert's suggestion that government may not exclude religion from its list of particularized considera-

58. "Mere" political thought might implicate distinctive and, arguably, less vital issues. See, e.g., John Rawls, A Theory of Justice 180-94, 475-80 (rev. ed. 1999) (arguing that a just society must prioritize liberty above the realization of "greater economic and social benefits"). Thus, there is not necessarily parity in protection for the two.

59. See, e.g., Street v. New York, 394 U.S. 576, 592 (1969) (reversing conviction for publicly maligning the flag on the grounds that the statute's goal, to prevent violent outbreaks, could have been served by a far narrower provision); United States v. O'Brien, 391 U.S. 367, 376-77 (1968) (ruling that law burdening political speech should be sustained only if "the incidental restriction on alleged First Amendment freedoms is no greater than is essential to the furtherance of that interest").

60. Smith, 494 U.S. at 879 . There have been some suggestions that, rather than strict scrutiny, the First Amendment should place an absolute bar on laws that seek to control religious beliefs. See id. ("[L]aws . . . cannot interfere with mere religious belief and opinions ....") (quoting Reynolds, 98 U.S. at 166); McDaniel v. Paty, 435 U.S. 618, 631-35 (1978) (Brennan, J., concurring) (arguing that a religious test for office is absolutely prohibited by the Constitution); Cantwell v. Connecticut, 310 U.S. 296, 303-04 (1940) (" $[\mathrm{T}]$ he amendment embraces two concepts,-freedom to believe and freedom to act. The first is absolute . . . .); Reynolds, 98 U.S. at 164 ("Congress was deprived of all legislative power over mere opinion ...."); Lipson, supra note 35, at 643. But see Wooley v. Maynard, 430 U.S. 705, 715-16 (1977) (applying strict scrutiny test to statute that arguably limited freedom of mind); Kent Greenawalt, Religion and Fairness: Free Exercise, ch. 3 at 8-13 (unpublished manuscript, on file with the Columbia Law Review). As Professor Greenawalt points out, the absolute bar position can be a bitter pill to swallow, especially where religious belief strongly foreshadows highly undesirable outcomes. Id. In addition, we seem to take for granted the validity of some criminal laws regulating, or at least penalizing, thought: Premeditation, for instance, can be an element or aggravator in a murder charge. Presumably, we believe that the state's interest in preventing calculated killing is sufficiently vital, and our alternatives slender enough, to support these statutes.

61. 374 U.S. 398 (1963); see Smith, 494 U.S. at 882-85.

62. Smith, 494 U.S. at 884.

63. For an alternative justification for the Sherbert exception, see Kaplan, supra note 36, at 1081-82. Kaplan argues that the Sherbert exception is intended to guard against the exercise of "unfettered discretion[ ]" by state actors in a demonstrably discriminatory manner. Id. I do not read her conclusion-that Sherbert is triggered only when officials 
tions without providing a compelling justification for doing so. ${ }^{64}$ It might be possible to argue that juror selection is similarly individualized: A challenge for cause calls for the judge to exercise discretion on a personby-person basis as to whether, on balance, the interests of society and the parties are best served by admission of a particular juror. Although Sherbert does not expressly require that states employ the least restrictive means available, it might be difficult to characterize an interest in a particular scheme as "compelling" when there is another way to accomplish the same goal with less harm. ${ }^{65}$

"discriminate between religious and secular reasons for granting individual exemptions," id. at 1083-as inconsistent with the one advanced in this Note.

64. See Church of the Lukumi Babalu Aye, Inc. v. City of Hialeah, 508 U.S. 520, 537-38 (1993) (holding that within system of individualized governmental assessment, government may not value religious reasons below secular reasons without compelling reason); Fraternal Order of Police Newark Lodge No. 12 v. City of Newark, 170 F.3d 359, 364-67 (3d Cir. 1999) (invoking Sherbert exception to require heightened scrutiny of police department policy permitting medical but not religious exceptions from no-beard rule); $\mathrm{cf}$. Bette Novit Evans, Interpreting the Free Exercise of Religion: The Constitution and American Pluralism 213-14 (1997) (suggesting that Sherbert could apply outside employment context); Christopher L. Eisgruber \& Lawrence G. Sager, The Vulnerability of Conscience: The Constitutional Basis for Protecting Religious Conduct, 61 U. Chi. L. Rev. $1245,1280,1282$ (1994) (same).

65. Smith also distinguishes its holding from a handful of prior decisions presenting a "hybrid" of free exercise and other constitutional claims. Smith, 494 U.S. at 881-82. The majority leaves rather mysterious the mechanics of combining free exercise with other claims in the future. Does the hybrid claim succeed only where the nonreligious claim would be strong enough to succeed on its own? If so, why bother to describe the claim as hybrid at all? See Lukumi, 508 U.S. at 566-67 (Souter, J., concurring). Justice Souter suggests that the entire hybrid exception is unworkable, since the only alternative he sees to the useless independently sufficient approach is one in which the mere presence of another claim is sufficient to bypass Smith. See id. at 567. In that case, there would be nothing left of Smith to bypass. There could also be a mathematical approach, where each fragment of a constitutional claim possesses a certain weight, and, when merged together, they add up to something great enough to prevail. Smith, however, is adamant that courts should not be in the business of assessing the strength of religious burdens. See Smith, 494 U.S. at 886-87. Little wonder, then, that the courts of appeals are split on the question of how to interpret the hybrid exception. Compare Thomas v. Anchorage Equal Rights Comm'n, 165 F.3d 692, 705 (9th Cir. 1999) (holding that plaintiff invoking hybrid exception need only make "colorable claim that a companion right has been infringed"), vacated on other grounds, 220 F.3d 1134 (9th Cir. 2000) (en banc), and Soc'y of Separationists, Inc. v. Herman, 939 F.2d 1207, 1216-17 (5th Cir. 1991) (applying pre-Smith precedent for juror's oath case based on theory that it was religion plus speech), with Brown v. Hot, Sexy \& Safer Prods., Inc., 68 F.3d 525, 539 (1st Cir. 1995) (holding that party must have independently sufficient claim to invoke hybrid exception), and Kissinger v. Bd. of Trs. of Ohio State Univ., 5 F.3d 177, 180 (6th Cir. 1993) (refusing to apply hybrid exception generally). Two other circuits have commented on the controversy without taking a definitive position. See Swanson v. Guthrie Indep. Sch. Dist. No. I-L, 135 F.3d 694, 700 (10th Cir. 1998) (noting hybrid exception requires at least a colorable claim of another right but might require more); EEOC v. Catholic Univ. of Am., 83 F.3d 455, 467 (D.C. Cir. 1996) (suggesting independently sufficient claim, in combination with free exercise claim, created an alternative ground for decision). Even if a court could agree on a workable standard for applying the hybrid exception, it would still have to guess as to the appropriate level of scrutiny that should accompany non-Smith claims. See Lipson, supra 


\section{The Likely Standard of Review}

To sum up, it appears that the fairly sweeping language of Smith will foreclose strict scrutiny of for-cause challenges of religiously motivated jurors unless those challenges can be shown to be either aimed at belief rather than conduct, or are part of a system of individual exemptions. As this Part has demonstrated, we can only describe mental activity as either belief or conduct after a thorough evaluation of public policy-an evaluation whose contours are themselves well described by the strict scrutiny process. ${ }^{66}$ Since "Witherspoon excludable" jurors are challenged based on their willingness to use a given mental process, the policy of for-cause exclusion must be examined under strict scrutiny. ${ }^{67}$ There is also a plausible argument that the Sherbert exception to Smith should apply, at least as that exception has been construed by the only court of appeals to have done so to date. ${ }^{68}$

note 35, at 645; William L. Esser IV, Note, Religious Hybrids in the Lower Courts: Free Exercise Plus or Constitutional Smoke Screen?, 74 Notre Dame L. Rev. 211,214 (1998). In view of these difficulties, there seems not much to be gained, for purposes of this Note, in speculating how for-cause exclusion might fit into such a ragged framework.

66. A court might engage in essentially the same policy inquiry, while avoiding what has been called the "rhetorical overkill" of the compelling interest/least restrictive means test, McConnell, supra note 28 , at 1128 , by finding that "[e]ffects on religious practice must be minimized, and can be justified only on the basis of a demonstrable and unavoidable relation to public purposes unrelated to the effects on religion." Michael W. McConnell \& Richard A. Posner, An Economic Approach to Issues of Religious Freedom, 56 U. Cbi. L. Rev. 1, 14 (1989).

67. The interests of the juror are heightened by the significance of the jury deliberation process. See, e.g., Powers v. Ohio, 499 U.S. 400, 407 (1991) (“[W]ith the exception of voting, for most citizens the honor and privilege of jury duty is their most significant opportunity to participate in the democratic process."). Some might say that there is not much harm to a juror who is refused a seat on a particular jury, when another seat is readily available. Cf. Lockhart v. McCree, 476 U.S. 162, 176 (1986) (noting that excluded jurors can still serve in other criminal cases). But there may still be harms to jurors who resent being denied an opportunity to participate in a decision that is of particular importance to them. Cf. J.E.B. v. Alabama ex rel. T.B., 511 U.S. 127, 153 (1994) (Kennedy, J., concurring) ("The injury is to personal dignity and to the individual's right to participate in the political process."). Nor is it clear why the opportunity to serve on another criminal jury matters if capital cases are the relevant universe of lost opportunity for rejected jurors. The Lockhart rationale leaves intact a system in which there are two castes of jurors: those who can invoke religion in capital cases and those who cannot. Cf. Kathleen M. Sullivan, Unconstitutional Conditions, 102 Harv. L. Rev. 1413, 1497-99 (1989) (condemning legal schemes whose effect is to reserve important rights for selected privileged groups). Both the dignitary harm and unconstitutional condition theories suggest that a juror categorically excluded from using fundamental religious beliefs in a prominent and controversial debate-e.g., the dispute over capital punishment in this country-may well lose his "'confidence in the fairness of the criminal justice system." Lockhart, 476 U.S. at 174-75 (quoting Taylor v. Louisiana, 419 U.S. 522, 530-31 (1977)).

68. These conclusions are based only on this Note's analysis of federal free exercise claims. Several states have rejected the logic of Smith in interpreting their own constitutions. Of these, the majority apply strict scrutiny even for incidental burdens on religious activity. See Ala. Const. of 1901 amend. 622, § V (1999); Conn. Gen. Stat. Ann. § 52-571b (West Supp. 2000); 775 1ll. Comp. Stat. Ann. 35/10 (West 1999); R.1. Gen. Laws 


\section{The Interests of THE State}

In most of its constitutional analysis, the Supreme Court has found that strict scrutiny requires the state to show that "its regulation is necessary to serve a compelling state interest and that it is narrowly drawn to achieve that end." 69 The jury selection cases present at least three possible governmental interests that might justify the free exercise infringement here. This Part considers these interests in turn. The first section addresses the need for an "impartial" jury. The section argues that impartiality in the capital sentencing context is different from nearly every other criminal jury decision in that the sentencing verdict rests not on facts but rather on a balance of moral factors. Traditional arguments for impartiality, therefore, are far weaker in the death penalty context. ${ }^{70}$ The second section considers the importance of voir dire in ensuring that jurors uphold the law. 1t argues first that the texts of most death penalty statutes, while hostile to absolute precommitments to one verdict or another, permit the use of religious views on the appropriateness of capital punishment in the weighing process. Alternately, this section goes on to suggest, where there is ambiguity as to whether a statute permits such usage or not, we ought to consult the traditional moral justifications for juries generally to determine whether jurors should have that power. It concludes, tentatively, that they should.

\section{A. The Right to an Impartial Jury}

The Bill of Rights guarantees every criminal defendant the right to trial by an "impartial jury."71 Certainly, the protection of constitutional rights can constitute a compelling state interest. ${ }^{72}$ Indeed, the Wither-

$\S 42-80.1$ to .3 (1998); S.C. Code Ann. $\$ \S 1-32-10$ to -60 (Law. Co-op. 1999); Matter of Dubreuil, 629 So. 2d 819, 822 (Fla. 1993); Rupert v. City of Portland, 605 A.2d 63, 65-66 (Me. 1992); Attorney General v. Desilets, 636 N.E.2d 233, 235-38 (Mass. 1994); Soc'y of Jesus v. Boston Landmarks Comm'n, 564 N.E.2d 571, 572-73 (Mass. 1990); McCready v. Hoffius, 586 N.W.2d 723, 729 (Mich. 1998); State v. Hershberger, 462 N.W.2d 393, 397-99 (Minn. 1990); First Covenant Church of Seattle v. City of Seattle, 840 P.2d 174, 185-88 (Wash. 1992); State v. Miller, 549 N.W.2d 235, 238-41 (Wis. 1996). Alaska requires a compelling government interest to sustain laws with incidental burdens on religious practices. See Swanner v. Anchorage Equal Rights Comm'n, 1994 AK 4081, II19-20, 874 P.2d 274, 280-82 (Alaska 1994). Two other states are less exacting, but still conduct some balancing between competing religious and state interests. See Abram v. City of Fayetteville, 661 S.W.2d 371, 372-73 (Ark. 1983) (permitting "reasonable limitation[s] upon the time, place, and manner" of religious activity); State v. Van Winkle, 889 P.2d 749, 754 (Kan. 1995) (requiring conditions of probation restricting religious freedoms protected under state constitution to bear "reasonable relationship" to goals of probation).

69. Widmar v. Vincent, 454 U.S. 263, 270 (1981).

70. This also means, of course, that the arguments in this Part would be of limited significance outside of capital sentencing.

71. U.S. Const. amend. VI.

72. See, e.g., Rosenberger v. Rector \& Visitors of the Univ. of Va., 515 U.S. 819, 837-46 (1995) (considering whether potential Establishment Clause violation justified viewpoint discrimination by state university). 
spoon cases repeatedly note that "[t]he State may insist . . . that jurors will consider and decide the facts impartially." ${ }^{3}$ That fact alone, however, does not imply anything about whether excluding certain jurors actually serves the interest of achieving impartiality. What, after all, is "impartiality"? Although Wainwright declared, somewhat conclusorily, that a standard permitting exclusion of jurors whose views would "substantially impair the performance of [their] duties"74 serves the interest of impartiality, the truth of this claim would seem to depend on just what we mean by impartial, impairment, and duty.

At a minimum, the state's definition of impartiality must be coherent. If the meaning of partiality itself cannot be fixed, then there is no legitimate basis for claiming that the exclusion of any particular juror advances the state any closer to the goal of an impartial jury: The goal is always receding or advancing tautologically, to whatever point the state can reach by a particular exclusion it desires. While the state may simply be deluded about the actual coherence of the ideal of impartiality, it would seem more likely in that circumstance that the desire to exclude a juror arises from something else (prosecutorial zeal, perhaps) and impartiality is only a pretext.

Modern cognitive theory places the coherence of a theory of jury impartiality in serious doubt. As one commentator has observed, the Founders' notion of impartiality was dependant on an Enlightenment-era notion that the world offered an objectively determinable truth that was accessible by careful and thoughtful human observations. ${ }^{75}$ A prime example of this view is John Marshall's description of an acceptable, unbiased juror, spoken in his role as presiding judge at the infamous treason trial of Aaron Burr in 1807. Marshall repeatedly used the metaphor of "impressions" on the minds of prospective jurors-often capturing the physical flavor of the metaphor's root in wax seals and printing presses: "It is too general a question to ask, whether [the juror] has any impressions about Colonel Burr. The impressions may be so light that they do not amount to an opinion of guilt, nor do they go to the extent of believing that the prisoner deserves capital punishment." 76 The outside world was a hard, definable thing to Marshall, like a piece of lead type, that might stamp rightly or wrongly upon the parchment of a given mind, but was always unchanged in itself.

Since Marshall's day we have come to think of his view of the world as "naïve." 77 The modern view is that our understanding of even "objective" data about the physical universe will depend significantly on our

73. Wainwright v. Witt, 469 U.S. 412, 420 (1985) (citing Adams v. Texas, 448 U.S. 38, $45(1980))$.

74. Id. at 424.

75. See Mark Cammack, In Search of the Post-Positivist Jury, 70 Ind. L.J. 405, 410-14 (1995).

76. United States v. Burr, 25 F. Cas. 55, 77 (C.C.D. Va. 1807) (No. 14,693).

77. Cammack, supra note 75 , at 409 . 
perspective or mental state when receiving such data. ${ }^{78}$ As Stanley Fish puts it, "Perception is never innocent of assumptions, and the assumptions within which it occurs will be responsible for . . . what is perceived."79 Our background, our culture, even our emotional state, influence our reception of the world so profoundly that it may be difficult for two people to agree that they are perceiving the same world. ${ }^{80}$

Under this view it might be difficult for the state to articulate its view of "impartiality" with enough specificity to avoid incoherence. In the strong form of the incoherence claim, there simply is no objective reality for a juror to be impartial in regard to. For most of us, though, this claim is just a bit too much. We believe that there is a world out there, albeit one about which it is sometimes difficult for us to communicate with each other. Still, even in its weak form, the incoherence problem is a significant barrier to the state's asserted interest in impartiality. If every jury is fundamentally biased in ways that are not easily understood, then it is hard to claim that excluding some jurors who profess a certain view is really much of an improvement in genuine impartiality. ${ }^{81}$

Nonetheless, the state might say, there are certainly some kinds of opinions that are definitely partial, in that they make it likely the juror will decide contrary to the facts as she herself understands them. For example, personal enemies of the defendant or those who stand to gain from her imprisonment are likely to return a dishonest ballot. In most criminal trials, then, where the jury's decision is dictated by findings on discrete questions of fact, ${ }^{82}$ the state's interest in excluding biased jurors seems clear. Impartiality is defined coherently in these cases, as truthful rendering of objective facts about the world. The state's capacity to identify jurors who are unlikely to meet this standard seems high.

78. See Hilary Putnam, How To Be an Internal Realist and a Transcendental Idealist (At the Same Time), in Language, Logic, and Philosophy 100, 105-08 (Rudolf Haller \& Wolfgang Grassl eds., 1980) (describing the view, first propounded by Berkeley and Kant, that our experience of any object is not of the object itself but rather of the object's "effect on us").

79. Stanley Fish, Why No One's Afraid of Wolfgang Iser, in Doing What Comes Naturally: Change, Rhetoric, and the Practice of Theory in Literary and Legal Studies 68, 78 (1989).

80. For philosophical elaboration on the problems of seeing the world and describing it, see Saul A. Kripke, Wittgenstein On Rules and Private Language 54-57, 85-86 (1982); Ludwig Wittgenstein, Philosophical Investigations 151-57, 197-216, 226-27 (G.E.M. Anscombe trans., 2d ed. 1958).

81. Recent social science descriptions of jury decisionmaking have observed that verdict outcomes are highly contingent on the initial attitudes of the jurors, the time and manner in which jurors receive additional information, and, in one model, the "narrative structure" jurors "impose[ ]" on the evidence. See Reid Hastie, Introduction to Inside the Juror: The Psychology of Juror Decision Making 3, 12-15, 18, 20, 24-26 (Reid Hastie ed., 1993)

82. See, e.g., N.Y. Penal Law $\S 155.42$ (McKinney 1998) (“A person is guilty of grand larceny in the first degree when he steals property and when the value of the property exceeds one million dollars."). 
Even so, the state's interest remains unclear where the jury's decision is not dependent upon purely factual determinations. ${ }^{83}$ The jury's death penalty decision is such a circumstance, in that the jurors' verdicts turn not on the existence of facts in the world but rather on the jurors' attitudes towards them. Under most of the capital punishment schemes in which juries may determine or recommend a sentence, the jury must find at least one statutory aggravating factor in order to recommend death. ${ }^{84}$ ln most instances these factors consist only of empirical facts-for example, whether the murder was "committed by a person [already] imprisoned as a result of a felony conviction." 85 These factual findings, though,

83. Cf. Riley v. State, 889 S.W.2d 290, 301 n.4 (Tex. Crim. App. 1993) (en banc) (arguing that under a fact-based inquiry, opposition to the death penalty would not prevent a juror from fulfilling her duty, but admitting that it is "arguable" that under the state's new weighing scheme, objectors could properly execute the law).

84. In some states, this determination is part of the sentencing hearing. See Ark. Code Ann. §5-4-603(a) (Michie 1997); Conn. Gen. Stat. $\$ 53 a-46 a(f)$, (i) (West Supp. 2000); Del. Code Ann. tit. 11, § 4209(d) (1995); Ind. Code Ann. § 35-50-2-9(a) (Michie 1998); Kan. Stat. Ann. § 21-4624(e) (1995); La. Code Crim. Proc. Ann. art. 905.3 (West 1997); Md. Ann. Code art. 27, § 413(f) (1996); Miss. Code Ann. § 99-19-101(3) (2000); Mo. Ann. Stat. $\S 565.030(4)$ (West 1999); Nev. Rev. Stat. Ann. 200.030(4)(a) (Michie 1997); N.H. Rev. Stat. Ann. \$630:5(IV) (1996); N.J. Stat. Ann. § 2C:11-3(c)(3) (a) (West 1995); N.Y. Crim. Proc. Law $\$ 400.27(11)$ (a) (McKinney 2000); N.C. Gen. Stat. $\$ 15 A-$ 2000 (c) (1999); Okla. Stat. Ann. tit. 21, $\$ 701.11$ (West 1997); 42 Pa. Cons. Stat. Ann. $\$ 9711$ (c)(1)(iv) (West 1998); S.C. Code Ann. $\$ 16-3-20$ (C) (Law. Co-op. 1996); S.D. Codified Laws § 23A-27A-4 (Michie 1998); Tenn. Code Ann. § 39-13-204(i) (1997); Wyo. Stat. Ann. $\$ 6-2-102$ (e) (Lexis 1999).

Several other states achieve the same result by making the aggravating factors elements of the offense to be charged and proved beyond reasonable doubt at trial. See Ohio Rev. Code Ann. $\S 2929.03$ (C) (2) (a), (D) (2) (West 1994); Utah Code Ann. § 76-5-202 (1999); Wash. Rev. Code Ann. $\$ 10.95 .020$ (West Supp. 2001).

85. Ark. Code Ann. $\$ 5-4604$ (1) (Michie 1997).

Some states allow the jury to find aggravation based on the somewhat more moral than factual question of whether the murder was especially cruel, heinous, inhuman, or the like. The Supreme Court has found, though, that these statutes are unconstitutionally vague under the Eighth Amendment unless further defined by state court decisions and/ or the trial judge's instructions. See Shell v. Mississippi, 498 U.S. 1, 2 (1990) (Marshall, J., concurring); Maynard v. Cartwright, 486 U.S. 356, 364-65 (1988). Many states now limit their "especially cruel" aggravator to specific factual situations, such as where the defendant has tortured the victim or mutilated his corpse. See N.H. Rev. Stat. Ann. $\S 630: 5$ (VII) (h) (1996); N.J. Stat. Ann. $§ 2$ C:11-3(C) (4)(c) (West 1995); S.D. Codified Laws § 23A-27A-I(6) (Michie 1998); Tenn. Code Ann. § 39-13-204(i)(5) (1997); Utah Code Ann. $\S 76-5-202(1)$ (q) (1999); Wyo. Stat. Ann. $\$$ 6-2-102(h) (vii) (Lexis 1999); State v. Breton, 562 A.2d 1060, 1066-67 (Conn. 1989); State v. Hamilton, 681 So. 2d 1217, 1226-27 (La. 1996) (reciting facts sufficient to meet Maynard standard); State v. Bonney, 405 S.E.2d 145, 155-56 (N.C. 1991) (same); State v. Martin, 278 S.E.2d 214, 220 (N.C. 1981) (same); Eddings v. State, 616 P.2d 1159, 1167-68 (Okla. Crim. App. 1980) (same), rev'd on other grounds sub nom. Eddings v. Oklahoma, 455 U.S. 104 (1982).

Other states continue to employ a broad heinousness aggravator. See Fla. Stat. Ann. § 921.141(5)(h) (West 1996); Kan. Stat. Ann. \$ 21-4625(6) (1995); La. Code Crim. Proc. Ann. art. 905.4(A)(7) (West 1997); Miss. Code Ann. $\$$ 99-19-101(5) (h) (2000); Mo. Ann. Stat. $\$ 565.032(2)(7)$ (West 1999). Delaware's broad provision has been held unconstitutionally vague by its supreme court but has not yet been remedied. See Del. 
are only the first step in a complex balancing to be undertaken by the sentencing juror. The jury must also determine that death is appropriate in light of possible mitigating factors. ${ }^{86}$ ln many cases, it must explicitly find that the permissible aggravating factors present outweigh the mitigating factors before recommending death. ${ }^{87}$ Some juries can also engage in an additional consideration of whether or not to reject death regardless of the balancing-out of mercy, for instance ${ }^{88}$ Consequently, assuming that jurors follow the prescribed process, ${ }^{89}$ it cannot be said that any determination is biased in the sense that it is dishonest about the facts of the case.

An additional problem for the state is that, for the most part, there is no way to know in advance how individual jurors will interpret and weigh the facts presented to them at sentencing. Thus, any given juror may be just as likely to harbor a predisposition towards one outcome-based on his reaction to the evidence and the judge's words-as the juror who has religious opinions about a death verdict. ${ }^{90}$ The state may be right to claim that jurors who state that they would "automatically" vote for or

Code Ann. tit. 11, $\$ 4209$ (e) (1) (1995); Bailey v. State, 503 A.2d 1210, 1212 (Del. 1984). Virginia's "depravity of mind" aggravator has, if anything, been broadened by state supreme court decisions, such that it now embraces victim impact testimony. See Va. Code Ann. \$ 19.2-264.4(C) (Michie 2000); Weeks v. Commonwealth, 450 S.E.2d 379, 389-90 (Va. 1994) (admitting victim testimony as probative of the "depravity of mind component of the vileness predicate"). The validity of a conviction relying on one of these statutory aggravators is open to question given the holdings of Shell and Maynard. Statutory aggravators remain, then, primarily factual.

86. See McKoy v. North Carolina, 494 U.S. 433, 442 (1990); Eddings, 455 U.S. at 110-12; Lockett v. Ohio, 438 U.S. 586, 604 (1978); Woodson v. North Carolina, 428 U.S. 280, 303-05 (1976) (opinion of Stewart, Powell, and Stevens, JJ.).

87. See Ark. Code Ann. \$ 5-4-603(a) (Michie 1997); Conn. Gen. Stat. Ann. § 53a46a(f) (West Supp. 2000); Del. Code Ann. tit. 11, $\$ 4209$ (c) (3) (a) (1995); Fla. Stat. Ann. $\$ 921.141$ (2) (West 1990); Ind. Code Ann. \$ 35-50-2-9(k) (Michie 1998); Kan. Stat. Ann. \$21-4624(e) (1995); Md. Ann. Code art. 27, § 413(h) (1996); Miss. Code Ann. § 99-19. 101 (3) (2000); Mo. Ann. Stat. $\$ 565.030$ (4) (West 1999); Nev. Rev. Stat. Ann. $§ 175.554(3)$ (Michie 1997); N.J. Stat. Ann. \& 2C:11-3(C) (3) (a)-(c) (West 1995); N.Y. Crim. Proc. Law $\$ 400.27$ (11) (a) (McKinney 1999) ("substantially outweigh"); N.C. Gen. Stat. \$15A2000 (c) (1999); Ohio Rev. Code Ann. \$ 2929.03(D) (2) (West 1997); Okla. Stat. Ann. tit. 21, § 701.11 (West 1997); 42 Pa. Cons. Stat. Ann. $\$ 9711$ (c)(1)(iv) (West 1998); Tenn. Code Ann. \$ 39-13-204(g)(1) (1997); Utah Code Ann. \$ 76-3-207(4)(b) (1999).

88. See Ark. Code Ann. § 54-603(b) (3) (Michie 1997); Mo. Ann. Stat. §565.030(4) (West 1999); Utah Code Ann. $\$$ 76-3-207(4) (b) (1999); Scott v. State, 529 A.2d 340, 345-46 (Md. 1987).

89. See infra Part III.B.1.

90. See William J. Bowers et al., Foreclosed Impartiality in Capital Sentencing: Jurors' Predispositions, Guilt-Trial Experience, and Premature Decision Making, 83 Cornell L. Rev. 1476 (1998). The authors, describing their empirical study of capital jury decisionmaking, report that many jurors made their determination based on "personal reasons or influences, including particular forms or kinds of evidence, aspects or characteristics of the defendant, the conduct of the prosecution or defense attorneys, and the like." Id. at 1496. In addition, sometimes "the defendant's demeanor throughout the guilt trial sbaped the juror's impression of his character." ld. The authors conclude, "These accounts suggest that jurors reach a premature decision on punishment both 
against the death penalty are predictably biased. ${ }^{91}$ Yet impartiality is still defined incoherently for every other member of the venire (i.e., the pool of potential jurors). As a result, it will still be difficult for the state to show that by excluding the "automatic" jurors it has made any gains toward an impartial jury.

Even so, might we not say that there are clearly some jurors who are more impartial than others? If so, won't exclusion of the least impartial jurors serve the state's purpose?92 While this observation has some force as applied to jurors who would certainly and "automatically" vote for or against a death verdict, it holds less water for any other juror. As the law has long recognized, jurors are rarely fully aware of the extent of their own biases. ${ }^{93}$ They may also have a limited capacity to communicate their views to the judge. Most significantly, all death penalty jurors are at sentencing prone, to an unknown extent, to the subjectivity biases described supra. ${ }^{94}$ In short, every juror is potentially "substantially impaired"-at least as to the mostly moral capital sentencing decision-to an extent equal to or greater than the excluded partial objector. In view of these uncertainties, it seems a stretch to describe as "compelling" an interest that can rarely, if ever, be definitively advanced.

The state might also reply that the ad hoc, tautological nature of impartiality is, in fact, no barrier to achieving its objective. After all, the state defines the factors that jurors are to consider. Why shouldn't the state also get to define what constitutes bias? One problem with this approach is that, given the great multiplicity of viewpoints in our society, the government's identification of some as "impartial" and some as "biased" unfairly privileges the "impartial" views and "delegitimizes the claims of those asserting that their voices are missing from the judicial process."95 In Smith, though, Justice Scalia dismisses the burdens on delegitimized groups as an "unavoidable consequence of democratic government." 96

because of their predispositions or attitudes and because of their experiences during the guilt trial." ld. at 1502.

91. See Morgan v. Illinois, 504 U.S. 719, 729 (1992).

92. See, e.g., id. at $734 \mathrm{n} .7$ (holding that although all veniremen are potentially biased, the purpose of voir dire is to eliminate those at either extreme).

93. See, e.g., United States v. Burr, 25 F. Cas. 55, 78 (C.C.D. Va. 1807) (No. 14,693) (statement of Mr. Wickham) ("[W]hen we object to a juryman [is it] . . for his want of honesty? No, sir, every man is subject to partialities and aversions, which may unconsciously sway his judgment. Mr. Upshaw does no doubt deem himself an impartial juryman; but Mr. Upshaw may be deceived.").

94. Cf. Wainwright v. Witt, 469 U.S. 412, 444 (1985) (Brennan, J., dissenting) ("When the time for decision arrives such [allegedly unbiased] jurors might or might not turn out to be so affected by the prospect of a death sentence in the case before them that they render a biased judgment; typically neither eventuality can be divined at the voir dire stage.").

95. Cammack, supra note 75 , at 456 .

96. Employment Div. v. Smith, 494 U.S. 872, 890 (1990). 
In any event, at bottom this claim is not based on the partiality of the juror per se, so much as the fact that the excluded juror is likely to transgress the law's standard of impartiality. Thus, we turn now to the state's interest in upholding the law.

\section{B. Upholding the Law}

The Witherspoon cases frequently advert to the state's interest in ensuring that jurors will "follow the law"97 or "conscientiously apply the law as charged by the court." 98 The cases are also generally in agreement that a juror who states categorically or gives substantial reason for suspecting that she will always return a verdict for or against death is "announcing an intention not to follow the instructions [of the judge]." ${ }^{\text {99 }}$ Thus, eliminating jurors who make such declarations for religious reasons would likely satisfy a compelling state interest. ${ }^{100}$ The next subsection, therefore, examines whether the letter of various capital sentencing laws is consistent with the use of preexisting juror preferences. It appears that in an overwhelming majority of states, there is a very strong textual argument that jurors can appropriately and legally apply their religious opinions to the work of "weighing" or "balancing" the required sentencing factors. ${ }^{101}$ In a handful of states-some important, because of the frequency with which their jurors return death verdicts-the law is simply ambiguous. Drawing on the work of Professor Ronald Dworkin, the second subsection argues that we might resolve our uncertainty in these states by observing that individualized moral decisionmaking by jurors at sentencing "fits" the traditions of our legal system and, therefore, should be presumptively legal. The result is that there is no illegal behavior for the state to target in seeking to "uphold the law."

1. The Letter of the Laws. - Do state and federal death penalty statutes actually have the effect of prohibiting to jurors recourse to their faith at sentencing? The answer to this question is complicated by the fact that modern capital juries at sentencing have an unusual double role. Under most schemes, the jury must first find whether or not there exists one or more statutorily defined "aggravating factors"102 or "special circum-

97. Wainwright, 469 U.S. at 421.

98. Adams v. Texas, 448 U.S. 38,45 (1980).

99. Morgan v. lllinois, 504 U.S. 719, 738 (1992).

100. Although not specifically familiar with any religion that would cause its adherents always to vote in favor of death, we might guess that a literal interpreter of the Old Testament might take that position.

101. At least for jurors whose religious beliefs make them reluctant to vote for death. Jurors whose faith points them in the opposite direction have very weak textual arguments in most states. See infra note 113 .

102. See, e.g., 18 U.S.C. $§ 3593$ (d) (2000) (directing that jury must find unanimously that one or more of the statutory or nonstatutory aggravating factors identified before trial by the government exists in order to impose sentence of death); Ala. Code $\$ 13 A-5-45(f)$ (1994) (requiring jury to find at least one aggravating factor to exist beyond a reasonable doubt in order to recommend a sentence of death). 
stances." 103 This determination is essentially identical to the typical factual finding conducted at the guilt phase of most trials. The jury is then usually instructed that they are to "weigh" the seriousness of the aggravating factors against a set of mitigating factors. ${ }^{104}$ In some states, the jury must also make findings about whether each mitigating factor has been established according to a certain level of proof. In many others, though, each juror is free to consider any factors that occur to him, even those not put forward by the defendant. ${ }^{105}$

It would seem, then, that in some states it should be possible to argue, much as Justice Scalia argues in his Morgan dissent, that the wording of the death penalty statute leaves open a textual argument that even flatout ex ante refusal to find aggravation is consistent with the law. For

103. Cal. Penal Code $\$ 190.2$ (a) (West 1999) (permitting death penalty only on finding of one or more of 21 statutory special circumstances, including "lying in wait" and use of a destructive device posing great risk of death). For other statutes enumerating required aggravating factors, see supra note 84 .

104. See supra note 87 .

105. A number of statutes expressly allow consideration of any mitigating factor. See 18 U.S.C. $\$ 3592$ (a) (2000) ("In determining whether a sentence of death is to be imposed on a defendant, the finder of fact shall consider any mitigating factor . . . .); Conn. Gen. Stat. Ann. § 53a-46a(d) (West Supp. 2000); Ky. Rev. Stat. Ann. \$ 532.025(2) (Michie 1999); Md. Ann. Code art. 27, $\S 413(\mathrm{~h})$ (2000); Ohio Rev. Code Ann. $\S 2929.04$ (B) (West Supp. 2000); S.C. Code Ann. $\$ 16-3-20$ (C) (Law. Co-op. 1999); S.D. Codified Laws $\$ 23 A-27 A-1$ (Michie 1998); Hall v. Wainwright, 733 F.2d 766, 774 n.11 (11 th Cir. 1984) (Florida statute allows consideration of any mitigating factor); White v. State, 403 So. 2d 331, 336 (Fla. 1981) (same). Other states note that available mitigating factors include but are not limited to those listed in the statute. See Ark. Code Ann. \$ 5-4605 (Michie 1997); Kan. Stat. Ann. § 21-4626 (1995); N.C. Gen. Stat. § 15A-2000(f) (1999); Va. Code Ann. § 19:2264.4(B) (Michie 2000); Wash. Rev. Code Ann. \$10.95.070 (West Supp. 2001). A similar approach, adopted by a few states, is to imply open-ended mitigation by stating that mitigating elements "include" the statutory factors. See Mo. Ann. Stat. $\$ 565.032$ (3) (West 1999); N.H. Rev. Stat. Ann. $\$ 630: 5(V I)$ (1996); N.Y. Crim. Proc. Law $\S 400.27(9)$ (McKinney 2001); 42 Pa. Cons. Stat. Ann. $\$ 9711$ (e) (West 2000); Utah Code Ann. § 76-3207(3) (1999); Wyo. Stat. Ann. §6-2-102(j) (Lexis 1999).

Yet other laws appear to track the constitutional minimum for mitigating factors set out in Lockett v. Ohio, 438 U.S. 586, 604-08 (1978) ("[S]entencer, in all but the rarest kind of capital case [must] not be precluded from considering, as a mitigating factor, any aspect of a defendant's character or record and any of the circumstances of the offense that the defendant proffers . ....") (citation omitted). See Del. Code Ann. tit. 11, $\S 4209$ (c) (3)a.2 (1995); Miss. Code Ann. § 99-19-101 (2000); N.J. Stat. Ann. § 2C:113(c) (5) (h) (West 2000); Tex. Code Crim. Proc. Ann. art. 37.071 \& 2(f)(4) (Vernon 2000); Wilcher v. State, 697 So. 2d 1087, 1103-04 (Miss. 1997). A fair construction of Lockett probably limits its mandate to mitigation stemming from the particular background or circumstances of the defendant and the crime, rather than general religious sentiments about capital punishment. Assuming the statutes mean to do no more than they must, they probably are also limited to individualized factors.

Lastly, a few statutes permit consideration of "any other mitigating circumstances" so that it is ambiguous whether "circumstances" includes an individual juror's general religious views on the death penalty. See Ind. Code Ann. $\$ 35-50-2-9$ (c) (8) (Michie 1998); Nev. Rev. Stat. Ann. 200.035(7) (Michie 1997); Tenn. Code Ann. \$ 39-13-204(e) (1) (1999) (declaring that court may, but need not, instruct on nonstatutory aggravating circumstances). 
example, the Illinois law in question in Morgan defines only one aggravating factor, contract killing. Otherwise, although commanded to "consider all the aggravating factors supported by the evidence and all the mitigating factors supported by the evidence," the jury is free to conclude that any given fact is either aggravating or mitigating, or neither. ${ }^{106} \mathrm{~A}$ juror who admits in voir dire that he does not plan to find any facts (other than contractual killing) to be aggravating does not contravene the language of the statute.

In most states, however, and under the federal scheme, when a juror finds that a factor defined as aggravating exists, she must then consider it as an aggravating factor to be weighed against the mitigation, if any. A juror might say, then, that her commitment against the death penalty does not mean she will refuse to recognize as aggravating the statutory factors. Instead, she might simply not find them weighty enough to merit capital punishment. Under this logic, the juror "weighs" a factor at sentencing, even though she believes at voir dire it will rarely be heavy enough to overcome her qualms about the penalty. Only in the case of a statute that specifically forbids consideration of the factors that weigh in the opposite direction for that juror would the juror actually be violating the language of the law. ${ }^{107}$ A somewhat more difficult question would be presented by a juror in a state like Georgia, in which a judge lists for the jury permissible mitigating factors, and the juror's own personal reason for opposing the death penalty categorically is not among them. ${ }^{108} \mathrm{Ar}$ guably, the juror is not following the letter of the law if she then counts her private sentiments as a balancing factor.

The success of this argument might turn on a semantic question about the meaning of "weigh." Is the act of considering competing factors still "weighing" when it is actually a foregone conclusion, a hollow gesture? The Court has said not, although one could see a reasonable argument in the other direction. ${ }^{109}$ The categorical, or "automatic," death penalty opponent, then, is not "weighing." Because she is therefore not following the law, the state has a compelling interest in excluding her.

What, then, of the juror who is only unlikely or reluctant to impose death? Suppose a venue where the personal qualms of the juror are per-

106. See Morgan v. Illinois, 504 U.S. 719, 742-43 (1992) (Scalia, J., dissenting). A similar argument might be available under the Mississippi statute, in which jurors must find tbat "sufficient aggravating circumstances exist as enumerated." Miss. Code Ann. § 9919-101(3)(b) (2000). An aggravator could be present but simply not "sufficient" in the juror's mind to merit a recommendation of death.

107. See Morgan, 504 U.S. at 742 (Scalia, J., dissenting).

108. See Ga. Code Ann. $\$ 17-10-30$ (b) (1997).

109. See Morgan, 504 U.S. at 729; cf. Eddings v. Oklahoma, 455 U.S. 104, 113-15 (1982) (holding that although sentencer may determine the weight given to mitigating evidence, it may not give zero weight). For the reasonable argument in the other direction, see Garvey \& Coney, supra note 26, at 338-39. 
missible mitigating factors. ${ }^{110}$ In these instances, the juror seems well within the law as long as she legitimately gives some consideration to the aggravating factors. Indeed, some commentators have suggested that statutes of this kind specifically call on jurors to exercise their own personal philosophy, including their religious beliefs. ${ }^{111}$ In these statutory schemes, the state's interest would be limited to preventing the possibility that the challenged juror would refuse to recognize a defined aggravating factor. ${ }^{112}$ Since no rational juror would do that when she could accomplish the same result through a permissible weighing, this will rarely rise to the level of a compelling government interest. ${ }^{113}$

110. See supra note 88; see also People v. Malone, 762 P.2d 1249, 1274 (Cal. 1988) (en banc) (holding verdict against death not unreasonable where based on sympathy for defendant, even though jury found expressly that the aggravating factors outweighed the statutory mitigating factors).

111. See Laura S. Underkuffler, Agentic and Conscientic Decisions in Law: Death and Other Cases, 74 Notre Dame L. Rev. 1713, 1724-25 (1999). Underkuffler's claim presumes that the community's moral views-to which a capital defendant is entitled-are duly represented by a sort of sampling, in which each juror follows her own conscience, rather than attempting to capture the moral sense of the community at large. ld. at 1725-26. Arguably, the Court's approval of jurors who harbor personal biases, but are willing to set them aside to follow the judge's instructions, see Witherspoon v. Illinois, 391 U.S. 510, 514 n.7 (1968), suggests a model in which jurors are expected to apply community standards of morality, rather than their own, even in statutes that seem to give wide latitude to juror discretion.

112. The state also has an interest in protecting the proceedings against contamination by morally wrong or irrelevant factors. In discussing "religious" motivations, though, this Note assumes that term will not embrace racial supremacism or other obviously irrelevant factors.

113. However, the textual arguments of pro-death penalty jurors are much weaker, and the state interest correspondingly stronger. Most states prohibit the use of any nonstatutory aggravating factors. See Ala. Code $\S 13 A-5-49$ (1975); Ark. Code Ann. § 5-4604 (Michie 1997); Cal. Penal Code $\$ 190.2$ (West 1999); Conn. Gen. Stat. $\$ 53 a-46 a(h)$ (1994); Kan. Stat. Ann. \$ 21-4625 (1995); La. Code Crim. Proc. Ann. art. 905.4 (West 1997); Md. Ann. Code art. 27, § 413(d), (f) (2000); Miss. Code Ann. \$ 99-19-101 (2000); Mo. Rev. Stat. $\S 565.032(2)$ (1999); Nev. Rev. Stat. 200.033 (2000); Ohio Rev. Code Ann. $\$ 2929.04$ (A) (West 1997); Okla. Stat. tit. 21, $\$ 701.11(2000) ; 42$ Pa. Cons. Stat. Ann. $\S 9711$ (d) (West 1998); S.C. Code Ann. § 16-3-20(c) (a) (Law. Co-op. 1996); S.D. Codified Laws § 23A-27A-1 (Michie 1998); Tex. Code Crim. Proc. Ann. art. 37.071 § 2(b) (Vernon 2000); Va. Code Ann. $\$ 19.2-264.4$ (C) (Michie 2000); Wyo. Stat. Ann. $\$ 6-2-102$ (h) (Lexis 1999); Vaught v. State, 410 So. 2d 147, 151 (Fla. 1982); Holmes v. State, 671 N.E.2d 841, 848 (Ind. 1996). But see Ga. Code Ann. \$17-10-30(b) (1997); Tamme v. Commonwealth, 759 S.W.2d 51, 54 (Ky. 1988). In a few states jurors may apply nonstatutory aggravating factors if and only if there is also at least one statutory aggravator present. See Del. Code Ann. tit. 11, § 4209(c) (3) (1995); N.H. Rev. Stat. Ann. § 630:5(IV) (1996); State v. Nichols, 877 S.W.2d 722, 731 (Tenn. 1994); State v. Gardner, 789 P.2d 273, 285-86 (Utah 1989). Some schemes further limit juror-created aggravating factors by restricting permissible aggravators to those identified by the prosecution before trial or before the sentencing hearing. See 18 U.S.C. \$ 3592(c) (2000); N.H. Rev. Stat. Ann. § 630:5(I) (b) (1996); Okla. Stat. tit. 21, $\$ 701.10(2000)$.

Since statutory aggravators are almost universally factual, see supra note 85 and accompanying text, a jury that must find at least one statutory aggravator necessarily must make at least one factual finding before imposing a death sentence. At the time of voir 
1n other states, though, the only place a juror's predisposition could be reflected is in the relative weightings of permissible factors. There is no statute that prescribes the absolute value of its factors, and any law that required a verdict of death upon the mere finding of any factor or combination of factors would probably be unconstitutional. ${ }^{114}$ Where each juror likely brings a different view on the relative weight of each factor, there seems little genuine state interest in excluding some jurors in what is essentially random fashion. ${ }^{115}$ To exclude a juror, then, simply because she will allow her religious beliefs to inform the relative weights of the sentencing factors, probably would violate the First Amendment.

2. Resolving Doubts in the Border States. - What, though, are we to do in states like Georgia, where at best, one might say, the text of state law and particularized jury instructions might leave it ambiguous as to whether jurors can use their preexisting views of the death penalty at sentencing? ${ }^{116}$ Perhaps the state has an interest in protecting its law even

dire, a judge cannot know whether or not the facts of the case will support a finding of aggravation to the requisite level of proof, which is often beyond a reasonable doubt. Thus, a juror who at voir dire is already ready to say that he is likely to impose death is in effect promising to be dishonest about the facts. Exclusion is appropriate for such jurors. See supra text accompanying notes 81-83.

A court might also distinguish religious motives against death from those in favor of it by relying on Justice O'Connor's remark that 'limiting the accused's use of the peremptory is 'a serious misordering of our priorities,' for it means 'we have exalted the right of citizens to sit on juries over the rights of the criminal defendant, even though it is the defendant ... who faces . . . death.” J.E.B. v. Alabama ex rel. T.B., 511 U.S. 127, 150 (1994) (O'Connor, J., concurring) (quoting Georgia v. McCollum, 505 U.S. 42, 61-62 (1992) (Thomas, J., concurring)).

114. For instance, although the Texas statute makes death "automatic" if the jury gives an affirmative answer to three questions, one of the questions requires jurors to weigh aggravating and mitigating factors. The Court has said that it is this latter element of discretion that makes the law constitutional. Jurek v. Texas, 428 U.S. 262, 272-73 (1976) (plurality opinion). But see Lockett v. Ohio, 438 U.S. 586, 604 n.11 (1978) (plurality opinion) ("We express no opinion as to whether the need to deter certain kinds of homicide would justify a mandatory death sentence ....").

115. According to one empirical study, a large percentage of jurors make up their mind about sentencing well before the judge's sentencing instructions, and overwhelmingly these jurors stick to their decisions. See Bowers et al., supra note 90 , at 1487-88, 1491-93. Although some of these jurors might simply be reaching the same decision after applying the judge's instructions, many are probably, in effect, ignoring the judge. See id. at 1490 (“[M] ost [jurors] boldly affirmed that they were convinced of what the punishment should be . . . before hearing the judge's sentencing instructions ...."). Other studies have suggested that capital juries have difficulty understanding the judge's instructions for the complex sentencing procedure. See Michael B. Blankenship et al., Jurors' Comprehension of Sentencing lnstructions: A Test of the Death Penalty Process in Tennessee, 14 Just. Q. 325, 325-29 (1997); James Frank \& Brandon K. Applegate, Assessing Juror Understanding of Capital-Sentencing Instructions, 44 Crime \& Delinq. 412, 419-23 (1998); James Luginbuhl, Comprehension of Judges' 1nstructions in the Penalty Phase of a Capital Trial, 16 L. \& Hum. Behav. 203, 203-07 (1992). Thus, there might not be much gained in the law-abiding quality of the jury by excluding religiously-motivated jurors.

116. The other states in this category are Delaware, Mississippi, New Jersey, Texas, and perhaps Indiana, Nevada, and Tennessee. See supra note 105. 
when hazy and uncertain. Yet if there is a strong interpretive tool to resolve close calls, and the tool suggests that a law has not been infringed, the state's interest is at least considerably weakened, if not undermined altogether. Applying the text alone, or the words of the judge, is an impoverished view of "law." After all, when words are ambiguous, or they leave us with further questions before we know for certain what they mean, we generally do not give up and go home. Instead, we create a list in our head of all the possible meanings, and then pare that list down as we reject options that are wildly out of context, or inconsistent with the conversation we have had up until now. Perhaps "the law" we ask jurors to follow, which we convey to them in words, is similarly subject to the tools we use to understand each other in everyday life.

This theory of "the law" is set out by Ronald Dworkin. ${ }^{117}$ Dworkin explains that any system of rules almost inevitably presents hard casesareas where the text of the existing law does not definitively resolve the question. The legal philosopher H.L.A. Hart describes a similar phenomenon, which he terms a "gap" in the law. ${ }^{118}$ Depending on one's view of the clarity of language, some or even all cases may actually turn out to be all gap and no rule. Since the law can provide no clear guidance to the decisionmaker, Hart says, it is appropriate for the decisionmaker to make a pure policy decision, based upon whatever criteria move her. ${ }^{119}$

Dworkin, however, rejects this contention, insisting that interpretations are necessarily bound and constrained at least by the principles underlying the texts upon which they draw. ${ }^{120}$ When the law has a gap, a person who is trying to follow the law will formulate some theory of legal interpretation and apply it to the text of the law in order to extrapolate the likely principle that governs the fuzzy area. ${ }^{121}$ The key distinction between this approach and Hart's is that, in Dworkin's view, his method is not a replacement for law; it is law. The process is the same for easy and hard cases, but it is only noticeable in the hardest ones. ${ }^{122}$

Lastly, it is very important to realize that the interpreter's results cannot be entirely result-driven. She is not writing new law; she is choosing among the possible, probably limited set of meanings for an existing law. That is why easy cases are "easy"; there is only one interpretation that is logically consistent with what has come before. Dworkin describes this idea as "fit." He says:

Judges ... may not read the abstract moral clauses as expressing any particular moral judgment ... unless they find it consistent in principle with the structural design of the Constitution as a whole, and also with the dominant lines of past constitutional

117. See Ronald Dworkin, Law's Empire 87-88 (1986).

118. H.L.A. Hart, The Concept of the Law 123, 147-54 (2d ed. 1994).

119. Id. at 251-54.

120. See Dworkin, supra note 117 , at $176-275$.

121. Id. at 87.

122. See id. at 353-54. 
interpretation by other judges. They must regard themselves as partners with other officials, past and future, who together elaborate a coherent constitutional morality, and they must take care to see that what they contribute fits with the rest. ${ }^{123}$

The significant point to note here is that later interpretations must be consistent not only on the surface--at the level of a bare holding-but also at a deep principled level. Once we can say, though, that the decision matches both the outcomes and principles of preceding authorities, then we are securely within "the law" whatever our conclusion. ${ }^{124}$

Is there an argument, then, that jurors can follow the underlying principles of the American jury-and hence the law-when employing a moral authority that might arguably be denied to them by a surface reading of a state statute and judge's instructions? This tension between community rulemaking in the abstract, and juror moral decisionmaking in the particular, has been played out in the debate over "jury nullification." Nullification generally refers to the act of a jury in acquitting a defendant despite the fact that the letter of the law appears to require a conviction. ${ }^{125}$ Proponents of nullification have long argued that the power of the jury to refuse to convict presents an important check against tyrannical or overzealous government. ${ }^{126}$ Jurors protected William Penn from hanging; they seriously undermined the force of Britain's seditious libel laws in the colonies; and they made John Hancock's smuggling business a continuing success, despite his numerous arrests. ${ }^{127}$ Obviously, though, these triumphant examples were against genuinely tyrannical regimes. It seems to be an open question whether such a vigorous defense of liberty is needed within a representative democratic system, though one scholar has suggested that the American tradition of nullification shows that we believe jurors ought to make political, as well as factual, decisions. ${ }^{128}$

The values cited by defenders of jury nullification continue to be relied upon by courts in defending the institution of the jury generally. For example, in Taylor $v$. Louisiana, ${ }^{129}$ the Supreme Court overturned the

123. Ronald Dworkin, Freedom's Law: The Moral Reading of the American Constitution 10 (1996).

124. See Dworkin, supra note 117 , at $410-13$.

125. See Alan Scheflin \& Jon Van Dyke, Jury Nullification: The Contours of a Controversy, Law \& Contemp. Probs., Autumn 1980, at 51, 56; see generally Jeffrey Abramson, We, the Jury: The Jury System and the ldeal of Democracy 57-95 (1994) (describing features of jury nullification). The argument for nullification, then, is necessarily a worst-case scenario for our jurors, most of whom will face only ambiguity as to whether the law forecloses their decisional process.

126. See, e.g., William M. Kunstler, Jury Nullification in Conscience Cases, 10 Va. J. Int'l L. 71, 71 (1969); Jack B. Weinstein, Considering Jury "Nullification": When May and Should a Jury Reject the Law to Do Justice, 30 Am. Crim. L. Rev. 239, 240-41, 244 (1993).

127. See Steven M. Warshawsky, Note, Opposing Jury Nullification: Law, Policy, and Prosecutorial Strategy, 85 Geo. L.J. 191, 196-202 \& n.58 (1996).

128. See Abramson, supra note 125 , at 61 .

129. 419 U.S. 522 (1975). 
conviction of a man who had been convicted by a jury drawn from a pool in which women had to file a special application in order to be eligible for service. The Court announced that the Sixth Amendment required juries to be drawn from a "representative cross-section" of the community, since " $[t]$ he purpose of a jury is to guard against the exercise of arbitrary power-to make available the commonsense judgment of the community as a hedge against the overzealous or mistaken prosecutor and in preference to the professional or perhaps overconditioned or biased response of a judge." 130 Rule-of-law considerations, along with problems of practical application, have limited the high ideals of Taylor. Recognizing that no random draw of a hundred or so people will necessarily sample all the significant viewpoints within a community, the Court has concluded that the cross-section requirement imposes strictures only on the venire rather than the jury actually selected. ${ }^{131}$

Nullification has also been the driving factor in the area of "special verdicts" or "juror interrogatories." Under federal law, in most circuits, a district court should ask a jury only whether the defendant is guilty or innocent of each count; it should not ask them to respond to a series of factual or legal questions, each individually insufficient for guilt but cumulatively equivalent to it. The traditional rationale for this policy has been that interrogatories pose a danger that the jury will be led "[b]y a progression of questions each of which seems to require an answer unfavorable to the defendant," to reach a verdict of guilty, when it might otherwise have-perhaps in defiance of logic-acquitted. ${ }^{182}$ Recent developments in criminal law, though, have placed increasing pressure on the rule against special verdicts. In complex drug conspiracy and racketeering cases, a court will often want to avoid having a retrial on every count in the event the defendant successfully appeals. One way to do that is to ask the jury to make specific findings as to the involvement of each defendant in each predicate act. If, for example, evidence of one of the underlying predicate acts is then ordered excluded by an appellate court, the verdict can still be shown to rest, undisturbed, on other predicates. Indeed, some circuits now recognize this situation as an exception to their rule against special verdicts. ${ }^{133}$ Similarly, with the rise of sentencing

130. Id. at 528-30.

131. See Lockhart v. McCree, 476 U.S. 162, I73-74 (1986).

132. United States v. Spock, 416 F.2d 165, 182 (1st Cir. 1969); accord United States v. Adcock, 447 F.2d 1337, 1339 (2d Cir. 1971) (per curiam). But see United States v. Ruggiero, 726 F.2d 913, 926-27 (2d Cir. 1984) (Newman, J., concurring in part and dissenting in part) (weighing Spock considerations along with similar policy concerns in concluding that "a District Court should have the discretion to use a jury interrogatory in cases where risk of prejudice to the defendant is slight and the advantage of securing particularized fact-finding is substantial").

133. See United States v. Ogando, 968 F.2d 146, 148-49 (2d Cir. I992); United States v. Aiello, 900 F.2d 528, 534 (2d Cir. 1990); United States v. Roman, 870 F.2d 65, 73 (2d Cir. 1989); Ruggiero, 726 F.2d at 922-23; United States v. Desmond, 670 F.2d 414, 418 (3d Cir. 1982); see also Kawakita v. United States, 343 U.S. 717, 737 (1952) (holding interrogatory 
schemes, like the federal drug laws, that place heavy emphasis on the facts of the case, a court will often be tempted to submit individual questions of fact-like the total weight of drugs-to a jury. ${ }^{134}$ These exceptions are so common to federal trials that the Ninth Circuit has now said that it is, essentially, abandoning the rule against special verdicts. ${ }^{135}$ Other courts have not followed suit, however.

One area of jurisprudence that does seem unambiguously to support the principle of nullification is the law of double jeopardy. Double jeopardy is not symmetrical; a defendant can obtain a new trial when the evidence against him is dubious, but the government cannot similarly retry a questionable acquittal. ${ }^{136}$ The inconsistency of the rules excludes judicial economy as a likely explanation for the heightened protection for the defendant. Similarly, if reducing the wear and tear or oppression of the defendant is the driving factor, why allow retrials after a hung jury? This leaves protection of the jury's right to acquit-on whatever basis it chooses-as the most plausible explanation. ${ }^{137}$

On the other hand, courts have often refused to instruct juries on their supposed "power" to nullify. The leading case is Sparf v. United States. ${ }^{138}$ ln upholding a trial court's instruction to the jury that they could not return a verdict of manslaughter, and over a vigorous pro-nullification dissent from Justice Gray, the first Justice Harlan emphasized that the function of judge as giver of law was essential to protecting "the stability of public justice, as well as the security of private and personal

appropriate to ensure jury has complied with defendants' constitutional right to finding of overt act in treason charge); United States v. North, 910 F.2d 843, 911 (D.C. Cir. 1990) (explaining Kawakita as requiring exception to interrogatory rule for constitutionally required findings of overt acts); Spock, 416 F.2d at 182 n.41 (noting Kawakita exception).

134. See United States v. Pforzheimer, 826 F.2d 200, 205-06 (2d Cir. 1987) (citing United States v. Orozco-Prada, 732 F.2d 1076, 1084 (2d Cir. 1984)); Ruggiero, 726 F.2d at 926 (Newman, J., concurring); United States v. Murray, 618 F.2d 892, 895 n.3 (2d Cir. 1980); see also United States v. Melvin, 27 F.3d 710, 716 (1st Cir. 1994) (finding interrogatories permissible where necessary to determine whether to sentence defendants for possessing automatic weapons or firearms generally); North, 910 F.2d at 911 (noting interrogatories permissible with defendant's consent to determine fair sentence); Desmond, 670 F.2d at 418 (holding interrogatories necessary when certain facts crucial in determining appropriate sentence); Spock, 416 F.2d at $182 \mathrm{n} .41$ (same). For example, in Orozco-Prada, the defendants, a set of money launderers, were convicted on a count of conspiring to distribute controlled substances. Orozco-Prada, 732 F.2d at 1078-79. The same count included, as its underlying substantive claim, allegations that the defendants had aided in the distribution of both marijuana and cocaine. Since the resultant sentencing ranges were greatly divergent, depending on whether or not the conspiracy involved cocaine, the panel found that the best course would be to remand, with the district court to employ a special interrogatory to guide its sentencing. 1d. at 1084 .

135. United States v. Reed, 147 F.3d 1178, 1181 (9th Cir. 1998) (holding use of special verdict should be a matter of district court discretion in each case).

136. See United States v. Scott, 437 U.S. 82, 91 (1978); United States v. Ball, 163 U.S. 662, 671 (1896). basis).

137. See Scott, 437 U.S. at 91 (holding jury's right of acquittal is final regardless of its

138. 156 U.S. 51 (1895). 
rights." 139 If every juror were free to follow his own theory of "the law," or her own personal moral system, there would be an intolerable unpredictability and inconsistency in the application of the law. ${ }^{140}$ This, of course, was the exact reason that the Supreme Court struck down Georgia's death penalty statute in Furman. ${ }^{141}$

We might conclude, then, that on balance the overall thrust of the law seems to be away from jury decisions that look like nullification, at least when it comes to general verdicts. This does leave open the question: Unpredictability and inconsistency are frequently invoked bogeymen, but what makes them so bad in the context of sentencing? Put another way, might the moral principles underlying the ban on "cruel and unusual" punishments, if added to our general analysis of the need for consistency in the criminal law, produce a different outcome?142

One likely principle is deterrence. In that scenario, a "cruel" punishment is one that overdeters. An "unusual" penalty might also fail as deterrent because potential criminals are not familiar enough with its sting to weigh its seriousness against the benefit of their designs. Unpredictable sentences, such as might result from jurors nullifying at the penalty phase, are at least "unusual" under this theory. ${ }^{143}$ But, in light of the predictability and seriousness of the inevitable life sentence in the event death is not imposed, it is hard to believe nullification at sentencing really could undermine the deterrent effect of murder sanctions. ${ }^{144}$

We could tell a similar story with a retributive theory of punishment. ${ }^{145}$ Irregular sentences undermine the public's sense that a sentence was justly matched to the defendant's culpability. In addition, they render a just correspondence between sentence and crime pure chance. This, although it lies beneath the surface of the various opinions, is the likely rationale of Furman and ensuing cases. When a defendant is sentenced to death for morally objectionable reasons, such as racism, or even for no reason at all-as in Justice Stewart's famous "struck by lightning" analogy ${ }^{146}$-it represents a failure of the law to guarantee a just pairing of punishment with culpability. The Furman solution, though, is not to foreclose all jury moral decisionmaking, but rather to balance the jury's power against the potential for misguided discretion. We have already

139. Id. at 106 .

140. See id. at 74; United States v. Dougherty, 473 F.2d 1113, 1134-37 (D.C. Cir. 1972).

141. See Furman v. Georgia, 408 U.S. 238, 242-43 (1972) (Douglas, J., concurring).

142. Id. (quoting U.S. Const. amend. VIII).

143. This Note leaves aside the question whether the death penalty overdeters in general, and so is "cruel" in this scheme.

144. Except, perhaps, in the case of defendants who are already serving a life sentence.

145. For an argument that the Eighth Amendment requires sentencing based on retributivist principles, see Scott W. Howe, Resolving the Conflict in Capital Sentencing Cases: A Desert-Oriented Theory of Regulation, 26 Ga. L. Rev. 323, 387-94 (1992).

146. Furman, 408 U.S. at 309 (concurring opinion). 
seen the outcome of that balance for our purposes: The state is not good enough at identifying ex ante jurors who are likely to apply "improper" moral judgment under the cloth of religious reasoning to justify the resulting burden on free exercise. ${ }^{147}$

If Professor Dworkin is right, then, it may not make sense to say that a death penalty juror is not "apply[ing] the law" simply because she ascribes her own weight to the statutory factors. ${ }^{148}$ Law, in his view, is made by the subjective reading of the interpreter, constrained by "fit." Where the letter of the law does not foreclose a juror's use of preexisting religious views about the death penalty, and the American tradition appears to embrace it, perhaps the state can no longer claim that the juror has defied the law. ${ }^{149}$

\section{Public Confidence in the Courts}

Another state interest might be found in the need to preserve an image of the courts as neutral and impartial arbiters of society's disputes. If the public believes that trials are slanted or unfair, there might be more resort to self-help or extra-legal remedies, rather than lawsuits, as well as destructive expressions of frustration with unfair verdicts. Citizens may also be less inclined to obey the orders of a biased court.

Public confidence analysis is complicated by the fact that the same legal rule might have different effects on the confidence of the parties, the jury, and the outside world. A rule empowering defendants to remove any juror they wish, for any reason, would certainly give defendants more confidence in the jury's verdict. The victim's relatives, though, would be equally likely to have the opposite reaction. To the extent that public confidence encompasses only observers with a personal interest in the outcome of the trial, expansion or contraction of the exclusionary power is often a wash. In other cases, although there is no private party with contrary fairness expectations, the public at large has certain moral

147. See supra notes 74-94 and accompanying text. It is worth emphasizing that this conclusion is limited to the area of capital sentencing. For other jury verdicts-where the law is more determinate, or the rule-of-law considerations stronger-one might well conclude that nullification does not fit United States law.

148. Wainwright v. Witt, 469 U.S. 412,423 (1985). In contrast, there is probably a reasonable argument that the kind of purely personal policy decisions described by Hart are not law. On the other hand, in a common law system, these policy decisions are likely to become law for the next generation of interpreters. Jurors, however, are not like common law judges; they are not bound by decisions made by previous decisionmakers in comparable circumstances.

149. Cf. Lockhart v. McCree, 476 U.S. 162, 197 (1986) (Marshall, J., dissenting) ("Representing the conscience of the community, the jurors at both stages 'unavoidably exercise a range of judgment and discretion while remaining true to their instructions and their oaths.'" (quoting Adams v. Texas, 448 U.S. 38, 46 (1980))); State v. Steckel, 708 A.2d 994, 1002 (Del. Super. Ct. 1996) (noting that jurors express their personal feelings in the process of balancing aggravating and mitigating factors); State v. Nichols, 877 S.W.2d 722, 731 (Tenn. 1994) (holding that as long as jury finds that defendant is statutorily deatheligible, it is free to employ any other factor in evaluating decision to recommend death). 
expectations it expects the courts to vindicate. Thus, the Court prohibits parties from peremptorily striking female or black jurors, even though these demographic groups might have real and statistically identifiable tendencies in particular cases..$^{150}$

Under these guidelines, confidence in the courts is actually maximized by prohibiting, rather than allowing, the for-cause exclusion of "substantially impaired" jurors. Some commentators have suggested that denying political privileges to identifiable political-as opposed to racial or gender-groups is as damaging to public confidence as racial exclusion. ${ }^{151}$ In this case, though, the damage to public confidence is unlikely to be severe, since the "groups" being excluded are not as easily identified-generally, the stubborn subsets of certain religions, plus an assortment of politically motivated persons who may or may not be correlated with certain traditionally disadvantaged populations. ${ }^{152}$ Even so, the jurors who are actually excluded are aware of the discrimination directed at them, and their own confidence might be damaged. In the long run, they represent a much bigger group than the litigants, even if their interest itself is less powerful. So, on balance, the state's confidence interest probably argues against exclusion. ${ }^{153}$

\section{CONCLUSION}

This Note has argued that it violates the First Amendment to exclude potential jurors whose religious beliefs make them substantially likely either to impose or refuse to impose the death penalty. That determination probably rests, most of all, on whether or not Employment Division $v$. Smith will guide the free exercise analysis. Even assuming that Smith does not govern, a defendant or juror resisting exclusion would need to show that, unlike jurors who would "automatically" reach their conclusion, a substantially impaired juror is no more harmful to the state's interests than any other juror who resides in what we now recognize as a complex and difficult-to-discern web of personal and moral views about the world.

150. See J.E.B. v. Alabama ex rel. T.B., 511 U.S. 127, 149 (1994) (O'Connor, J., concurring) (explaining that despite correlations between potential juror's race or gender and their decisionmaking, strikes on that basis are constitutionally illegitimate because the justice system is making "a statement about what this Nation stands for" (quoting Brown v. North Carolina, 479 U.S. 940, 941-42 (1986) (O'Connor, J.) (opinion concurring in denial of certiorari))). Admittedly, this might be a statement based on an absolute moral imperative, rather than subjective public values, but if the community expects moral behavior from its courts, the result is the same.

151. See Andrew D. Leipold, Constitutionalizing Jury Selection in Criminal Cases: A Critical Evaluation, 86 Geo. L.J. 945, 986 (1998).

152. But see Wainwright, 469 U.S. at 440,442 (Brennan, J., dissenting) (arguing that jurors resistant to imposing death penalty are an identifiable group).

153. This conclusion is especially strong if we think that public confidence in the courts is undermined by a jury selection system that encourages rational jurors to lie about their beliefs during voir dire. 
There are at least two doctrinal hooks on which litigants seeking to distinguish Smith can hang their hats. First, in accordance with longstanding legal respect for freedom of thought, Smith might be interpreted to except from its prohibition on balancing laws that seek to restrict or control mental processes, even where those laws are neutral and of general applicability. Free exercise jurisprudence suggests that strict scrutiny is probably the proper approach in those cases. Secondly, following a suggestion in Smith and Lukumi, we might conclude, as did the Third Circuit, that where the government sets up a system in which it gives individualized consideration to each person, it may not ignore or devalue the religious beliefs of those it considers without providing a compelling reason for doing so.

Assuming that heightened scrutiny is appropriate, it is unlikely that most states could demonstrate a sufficiently compelling interest to justify the exclusion of religiously motivated jurors. It might be said that the goal of voir dire is to reduce error costs-that is, to exclude jurors who will render factually wrong outcomes. Death penalty verdicts are unusual, though, in that within a certain range of results, there are no wrong answers, only morally divergent ones. As long as the jury does not, for instance, return a verdict of death when the law requires the presence of certain aggravating facts, and those facts are not present, there is no "error" to avoid. Probably even for Professor Dworkin, who maintains that moral questions in the law do have "right" answers, the religious-but not the racist-juror is "right" whatever her vote, because her exercise of that discretion is consistent with our legal tradition.

What is more, most states cannot claim that jurors who are ex ante only likely or inclined to vote for or against the death penalty are likely to threaten the state's interest in upholding the law. Only in Delaware, Mississippi, New Jersey, Texas, and, arguably, in Georgia, Indiana, Nevada, and Tennessee are there serious textual arguments that a juror cannot use his or her personal religious beliefs in weighing whether or not to impose death. Even in these states, we expect-and, especially in the death penalty context, need-jurors to make full use of their range of moral learning. It might even be unjust for us to bar out of hand the use of a citizen's most central moral tenets, particularly when that citizen is being called upon to make what the law itself deems a deeply personal judgment. If nothing else, we should not enact these limits without reflecting carefully on our justifications for them.

In summary, then, it appears that where a potential juror's preconceived notions about the death penalty rest on religious grounds, the trial court should employ the fairly narrow Witherspoon standard over the broad Witt "substantially impaired" test. Court would add a question during voir dire: "Are the opinions you have just expressed based upon your religious or spiritual beliefs?" If a juror answers yes, and seems to be truthful in that avowal, she can only be excluded if she answered the question "Could you ever impose the death penalty?" unequivocally "no," 
or the question "Would you impose the death penalty in every case of capital murder?" unequivocally "yes."

It might fairly be said that these sentiments, while noble, pale in comparison to the importance of the jury's sentencing decision to the defendant. This project is misguided, then, if it leads to an elevation of a pro-death penalty juror's right to sit above the life of the defendant. It might be an answer to point out that the state's interest in preventing bias and upholding the law is much stronger in the case of pro-death jurors, largely because the juror's textual argument is much weaker. In nearly every state, and in the federal system, death may not be imposed except upon a factual finding of statutorily defined aggravating circumstances. Thus, the traditional fact-oriented approach to for-cause challenges might be appropriate. Alternately, we might look for states to revise their statutes to give judges the discretion to reject jury death verdicts. 